\title{
ADENOPHORA LILIIFOLIA: Condition of its Populations in Central Europe
}

\author{
Romana Prausovála*, Lucie MarečKová ${ }^{2 a}$, AdAm Kapler ${ }^{3}$, L'uboš MajeskÝ ${ }^{2}$,

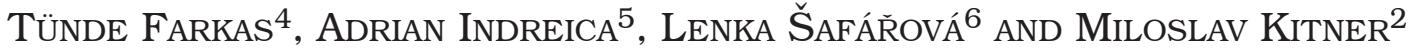 \\ ${ }^{1}$ University of Hradec Králové, Faculty of Science, Department of Biology, \\ 50002 Hradec Králové, Czech Republic \\ ${ }^{2}$ Palacký University in Olomouc, Faculty of Science, Department of Botany, \\ Šlechtitelů 27, 78371 Olomouc-Holice, Czech Republic \\ ${ }^{3}$ PAS Botanical Garden - Center for Biological Diversity Conservation in Powsin, \\ Prawdziwka 2, 02-973 Warsaw 76, Poland \\ ${ }^{4}$ Aggteleki Nemzeti Park Igazgatóság, Tengerszem oldal 1, 3759 Jósvafö, Hungary \\ ${ }^{5}$ Transilvania University of Brasov, Faculty of Forestry, Şirul Beethoven - 1, \\ 500123 Braşov, Romania \\ ${ }^{6}$ East Bohemian Museum in Pardubice, Zámek 2, 53002 Pardubice, Czech Republic
}

Received June 16, 2016; revision accepted September 30, 2016

\begin{abstract}
This study deals with populations of the European-South-Siberian geoelement Adenophora liliifolia (L.) A. DC. in the Czech Republic, Slovakia, Hungary, Romania, and Poland, where this species has its European periphery distribution. We studied the population size, genetic variability, site conditions, and vegetation units in which A. liliifolia grows. Recent and historical localities of $A$. liliifolia were ranked into six vegetation units of both forest and non-forest character. A phytosociological survey showed differences in the species composition among localities. Only a weak pattern of population structure was observed (only $22 \%$ of total genetic variation present at the interpopulation level, AMOVA analysis), with moderate values for gene diversity $\left(\mathrm{H}_{\mathrm{j}}=0.141\right)$ and polymorphism $(\mathrm{P}=27.6 \%)$. Neighborjoining and Bayesian clusterings suggest a similar genetic background for most of the populations from Slovakia, the Czech Republic, and Poland, contrary to the populations from Hungary, Romania, as well as two populations from Central and South Slovakia. This might be explained by a relatively recent fragmentation of the A. liliifolia populations in Central Europe. Nevertheless, it seems that several populations in Romania, South Hungary, and Slovakia were isolated for a longer period of time and their genetic differentiation is more evident.
\end{abstract}

Keywords: AFLP, Campanulaceae, European periphery distribution, declining population, EuropeanSouth-Siberian geoelement, genetic variability, vegetation

\section{INTRODUCTION}

The present-day flora of Central Europe reflects its geographic position, varied geology and topography, as well as climate and vegetation history, and it is influenced by glacial cycles during the Quaternary Period (Grulich, 2012; Kaplan, 2012). Numerous species that are extinct in Central Europe survived in Eastern Asia (e.g., Platycladus orientalis (L.) Franco (Farjon and Filer, 2013)), in Transcaucasia (e.g., Pterocarya pterocarpa

\footnotetext{
* Corresponding author, email: romana.prausova@uhk.cz

a These two authors contributed equally to this work.
}

(Michx.) Kunth ex Iljinsk. (Denk et al., 2001)), or in the Balkan Peninsula (e.g., Picea omorika (Pančić) Purk. (Ravazzi, 2002)). Some species, such as Ligularia sibirica (L.) Cass. (Šmídová et al., 2011) or Pedicularis sudetica Willd. (Hendrych and Hendrychová, 1988), became glacial or postglacial relicts, but also new local endemics appeared, e.g., Galium sudeticum Tausch, G. cracoviense Ehrend., Cochlearia polonica E. Froelich (Cieślak et al., 2007, 2010, 2015; Cieślak and Szelag, 2009, 2010; Koláŕ et al., 2013, 2015) or Sorbus sudetica (Tausch) Bluff et al. (Kaplan, 2012). Climatic 
changes during the Quaternary Period strongly affected the species composition and the species distribution in Europe (Szafer, 1946-47, 1954; Kaplan, 2012). Since the Neolithic Period, humans have become another important factor affecting the regional floras (Szymura, 2012; Hejcman et al., 2013; Roleček et al., 2014; Plieninger et al., 2015).

Many species, such as A. liliifolia (L.) A. DC, changed their distribution and their recent presence in floras is highly influenced by human activity. A. liliifolia is considered to represent the EuropeanSouth-Siberian geoelement, which tolerates extreme continental climate with a short growing season, warm but short summers, and long winters with severe frosts (Kucharczyk, 2007; Kaplan, 2012; Kucharczyk et al., 2014). The centre of A. liliifolia distribution is in Western Asia-Southern Siberia, and from there it extends to Mongolia and Western China in the East, and to the North-West of Turkey, and to South-, Eastern-, Central- Europe up to Western Europe in the West (Tacik, 1971; Fedorov, 1978; Deyuan et al., 2011; Urgamal, 2014). Although Smelansky et al. (2004) reported A. liliifolia as a common species in the steppes and foreststeppes in Southern Siberia, Boronnikova (2009) reported a $25 \%$ decrease of populations in the Perm region (Ural, Russia) during the last 15 years due to agricultural activities in the territory. Also, in the whole Central European region, A. liliifolia populations are declining not only in the number of localities, but also in the number of plants representing a single population.

A. liliifolia is scattered across Europe and forms isolated populations in Germany (Meusel and Jäger, 1992; Castroviejo et al., 2010), Austria, Switzerland (Moser, 1999), Italy, Czechia (Martinovský, 1967; Kovanda, 2000), Poland (Witkowski et al., 2003; Korzeniak and Nobis, 2004; Ciosek, 2006; Kapler et al., 2015), Slovakia (Goliášová and Šípošová, 2008), Hungary (Farkas and Vojtkó, 2012, 2013; Vojtkó, 2013), Croatia, Bosnia and Herzegovina, Montenegro, Serbia (Vladimirov et al., 2009; Vukojičić et al., 2011), Romania (Jones et al., 2010; Indreica, 2011), and Slovenia (Babij, 2004; Acetto, 2007). In Belarus, the species was thought to be extinct (Kozlovskaja, 1978), but one population at Sporowski Zakaznik was restored with plants multiplied in vitro and cultivated in the Minsk Botanical Garden of the Belarussian Academy of Sciences (Wiliams and Gotin, 2012). The information about A. liliifolia from France (Schnittler and Günther, 1999) and Bulgaria (Dimitrov, 2002) is uncertain, as no herbarium records from France and the current Bulgarian territory exist.

A. liliifolia is protected in Europe according to the Directive on the conservation of natural habitats and of wild fauna and flora (92/43/EEC); it is considered as a species of least concern (Bilz et al., 2011); and it is threatened by vigorous shrubby vegetation and by inappropriate forest management (Anonymous, 2009). A. liliifolia is considered a plant species of European Community interest, whose conservation requires designation of special areas of conservation. Moreover, it is an indicator species of thermophilous forest hotspots, signaling remnant pools of biodiversity (Kiedrzyński et al., 2015). A typical habitat of A. liliifolia is the coppice, which is a formerly widespread way of forest management. However, changes in landscape management during the last two centuries caused the extinction of this species because of the shady and more eutrophicated high forests (often with conifers) that replaced the coppices (Szymura, 2012; Müllerová et al., 2015). Today A. liliifolia grows in lowlands in small populations in remnants of former light oak forests, their ecotones, and adjacent meadows. At higher altitudes it grows on the rocky outcrops in beech forests (Moser, 1999; Dražil, 2002), and in the portions of riparian forests receiving large quantites of sunlight (Siklósi, 1984; Farkas and Vojtkó, 2012, 2013). These ecological demands make A. liliifolia a suitable model species for studying the changes and the impact of human activities on populations of species with similar characteristics.

In spite of the critical conservation status of A. liliifolia in Europe, no large-scale population genetic studies have been done so far. Only two studies have investigated the population structure of A. liliifolia: Boronikova (2009) analyzed four populations from the Ural region (Perm, Russia), and Manole et al. (2015) described the genetic diversity of one A. liliifolia population from Romania. The present study aimed to provide overall information on the current condition of A. liliifolia populations in Central Europe, and thus to better know the factors threatening this species and suggest appropriate management for the current populations. We performed: 1) a survey and comparison of A. liliifolia populations in Czechia, Slovakia, Hungary, Romania, and Poland; as well as 2 ) a screening of the genetic variability and relationship among the studied populations by means of Amplified Fragment Length Polymorphism (AFLP).

\section{MATERIALS AND METHODS}

\section{STUDY SPECIES}

The lilyleaf ladybells Adenophora liliifolia is a herbaceous perennial diploid $(2 \mathrm{n}=34)$ plant from the Campanulaceae family with erect, leafed and branched stems. The root is spindle-shaped or branched. The plant usually grows to a height of 
40-90 cm (Kovanda, 2000), although plants with heights of $205 \mathrm{~cm}$ have been observed in Poland (Ciosek, 2006). Basal leaves and leaves of young plants are long petiolate, with cordate to rounded and coarsely serrate blades. Stem leaves are sessile, alternating with an elliptical to lanceolate, serrate to entire blade with a wedge-shaped base. Inflorescences are panicles or racemes, flowers are fragrant. Calyx lobes are triangular, pointed, 3-4 mm long and finely serrate. The corolla is bell-shaped, 12-20 mm long, pale blue, rarely white. The pistil is twice as long when compared to the corolla. The species flowers from late June to August and is pollinated by insects. The fruits are pear-shaped, curved, 8-12 mm long capsules, opening with three holes at the base. The seeds are flattened, reddish brown, from $2.0-2.5 \mathrm{~mm}$ long and are spread by wind (Kovanda, 2000; Kucharczyk et al., 2014). The precise ecological demands of $A$. liliifolia require further studies. According to Ellenberg et al. (1992), the ecological demands are as follows: light $(\mathrm{L})=7$; temperature $(\mathrm{T})=6$; continentality $(\mathrm{C})=6$; moisture $(\mathrm{F})=6$; soil reaction $(\mathrm{R})=8$; nutrients $(\mathrm{N})=2$.

\section{CHARACTERISTICS OF A. LILIIFOLIA POPULATIONS AND THEIR LOCALITIES}

Monitoring in Czechia, Slovakia, Hungary, and Romania was performed according to the Natura 2000 methodology (Marhoul and Turoňová, 2008) during July and August in 2012 or 2013. The number of tufts and number of fertile and sterile stems in each tuft were determined at each locality in all the countries. The condition of the locality and its changes were observed during the monitoring of populations in 2012-2013. The danger of possible damage such as grazing, drying, grubbing out, damage from human activities, etc., was qualitatively recorded. Morphological differences including stem height, number of leaves per stem, length and width of 3 leaves at the central part of the stem, and number of branches and flowers in an inflorescence were observed too. Information about the Polish localities of Kisielany and Dabrowa originates from papers by Ciosek (2006) and Rapa (2012). In total we studied 23 localities (all current localities in Czechia, Slovakia; chosen representative and accesible localities in Romania, Hungary, and Poland (Fig. 1). The characteristics of the studied localities are shown in Tab. 1 and Fig. 2, and were summarized from published data (Comitetul de Stat al Geologiei - Institutul Geologic CSG-IG, 1968; Mihai, 1975; Miklós, 2002; AOPK ČR, 2005; Káčer et al., 2005; Cháb et al., 2007; Tolasz, 2007; European Soil Data Center, 2008-2015; Dövenyi, 2010; Climate Change Knowledge Portal, 2015; IUSS Working Group WRB. 2015; One Geology Europe, 2015).

The localities were ordinated with Principal Component Analysis (PCA). The climatic characteristics (annual mean temperature, annual precipitation), the altitude, affiliation with particular biogeographic regions in Europe, and forest/non-forest character of vegetation were used as supplementary data to assist with data interpretation. The calculations were done in the CANOCO 4.5 program (ter Braak and Šmilauer, 2002).

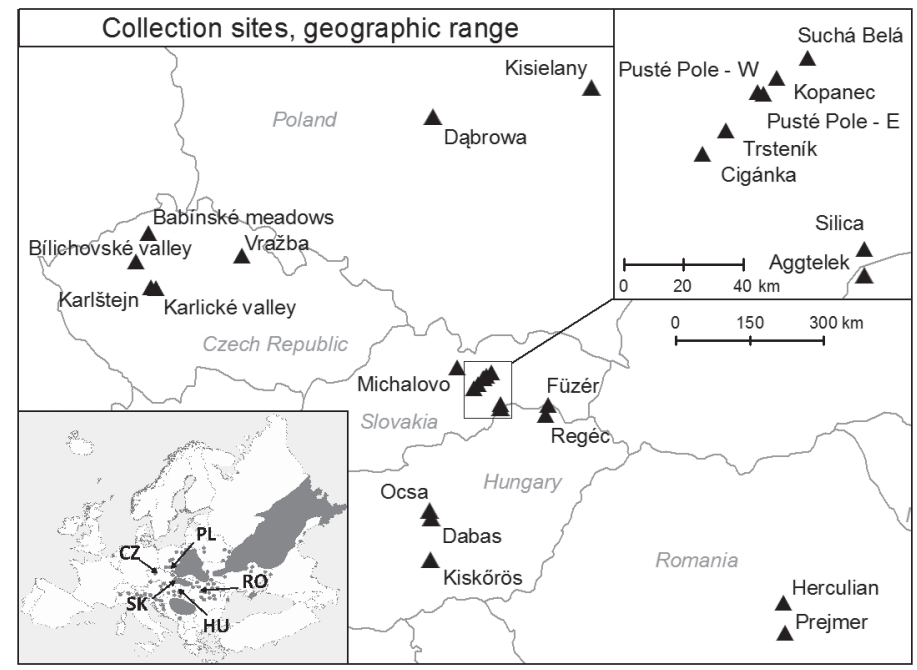

Fig. 1. Map of the studied localities of A. liliifolia in Czechia, Slovakia, Poland, Hungary and Romania and its geographic range (made by J. Gamrát in ArcGIS 10 program). 
TABLE 1. Site conditions of the studied localities (GPS coordinates indicate the approximate center of the locality)

\begin{tabular}{|c|c|c|c|c|c|}
\hline Site & $\begin{array}{l}\text { Latitude } \\
\text { Longitude }\end{array}$ & $\begin{array}{l}\text { Alt. } \\
(\mathrm{m})\end{array}$ & Bedrock & $\begin{array}{c}\text { Soil } \\
\text { (acc. to WRB 2014) }\end{array}$ & Habitat acc. o EH Habitat Directive \\
\hline \multicolumn{6}{|c|}{ Czechia } \\
\hline $\begin{array}{l}\text { Babínské } \\
\text { meadows }\end{array}$ & $\begin{array}{l}50^{\circ} 35^{\prime} 52^{\prime \prime} \\
14^{\circ} 07^{\prime} 36^{\prime \prime}\end{array}$ & 538 & mesozoic marl, claystone & $\begin{array}{l}\text { eutrophic cambisol, } \\
\text { planosol, stagnosol }\end{array}$ & Intermittently wet Molinia meadows \\
\hline $\begin{array}{l}\text { Bílichovské } \\
\text { valley }\end{array}$ & $\begin{array}{l}50^{\circ} 15 ’ 51^{\prime \prime} \\
13^{\circ} 53^{\prime} 57^{\prime \prime}\end{array}$ & 429 & mesozoic marl, claystone & cambisol & Oak-hornbeam forest \\
\hline Karlické valley & $\begin{array}{l}49^{\circ} 57^{\prime} 07^{\prime \prime} \\
14^{\circ} 15^{\prime} 24^{\prime \prime}\end{array}$ & 325 & paleozoic limestone & cambisol & Oak-hornbeam forest \\
\hline Karlštejn & $\begin{array}{l}49^{\circ} 57^{\prime} 35^{\prime \prime} \\
14^{\circ} 10^{\prime} 24^{\prime \prime}\end{array}$ & 400 & paleozoic limestone & cambisol, phaeozems & $\begin{array}{l}\text { Central European basiphilous } \\
\text { thermophilous oak forest }\end{array}$ \\
\hline Vražba & $\begin{array}{l}50^{\circ} 20^{\prime} 05^{\prime \prime} \\
15^{\circ} 49^{\prime} 19^{\prime \prime}\end{array}$ & 330 & mesozoic marl, claystone & cambisol & Oak-hornbeam forest \\
\hline \multicolumn{6}{|c|}{ Hungary } \\
\hline Aggtelek & $\begin{array}{l}48^{\circ} 31^{\prime} 14^{\prime \prime} \\
20^{\circ} 33^{\prime} 08^{\prime \prime}\end{array}$ & 495 & light steinalm limestones & $\begin{array}{l}\text { modal cambisol, } \\
\text { chernozem, } \\
\text { kastanozem }\end{array}$ & Mountain hay meadows \\
\hline Dabas & $\begin{array}{l}47^{\circ} 10^{\prime} 04^{\prime \prime} \\
19^{\circ} 16^{\prime} 03^{\prime \prime}\end{array}$ & 100 & $\begin{array}{l}\text { organic rich sediment, } \\
\text { lacustrine and paludal clay, } \\
\text { silt, calcareous mud, peat }\end{array}$ & $\begin{array}{l}\text { histosol, planosol, } \\
\text { stagnosol }\end{array}$ & Riparian mixed gallery forests \\
\hline Füzér & $\begin{array}{l}48^{\circ} 33^{\prime} 42^{\prime \prime} \\
21^{\circ} 25^{\prime} 13^{\prime \prime}\end{array}$ & 520 & rhyolite, andesite & $\begin{array}{l}\text { stagnosol, fluvisol, } \\
\text { podsol, retisol, } \\
\text { phaeozem }\end{array}$ & Intermittently wet Molinia meadows \\
\hline Kiskőrös & $\begin{array}{l}46^{\circ} 39^{\prime} 11^{\prime \prime} \\
19^{\circ} 16^{\prime} 29^{\prime \prime}\end{array}$ & 104 & $\begin{array}{l}\text { organic rich sediment, } \\
\text { lacustrine and paludal clay, } \\
\text { silt, calcareous mud, peat }\end{array}$ & $\begin{array}{l}\text { histosol, planosol, } \\
\text { stagnosol }\end{array}$ & Riparian mixed gallery forests \\
\hline Ocsa & $\begin{array}{l}47^{\circ} 15^{\prime} 42^{\prime \prime} \\
19^{\circ} 15 ’ 35^{\prime \prime}\end{array}$ & 247 & $\begin{array}{l}\text { organic rich sediment, } \\
\text { lacustrine and paludal clay, } \\
\text { silt, calcareous mud, peat }\end{array}$ & $\begin{array}{l}\text { histosol, planosol, } \\
\text { stagnosol }\end{array}$ & Riparian mixed gallery forests \\
\hline Regéc & $\begin{array}{l}48^{\circ} 26^{\prime} 19^{\prime \prime} \\
21^{\circ} 21^{\prime} 56^{\prime \prime}\end{array}$ & 680 & andesite & $\begin{array}{c}\text { histosol, fluvisol, } \\
\text { podsol, andosol }\end{array}$ & Intermittently wet Molinia meadows \\
\hline \multicolumn{6}{|c|}{ Poland } \\
\hline Dąbrowa & $\begin{array}{l}50^{\circ} 45^{\prime} 55^{\prime \prime} \\
22^{\circ} 09^{\prime} 02^{\prime \prime}\end{array}$ & 200 & $\begin{array}{l}\text { outwash sands and gravels, } \\
\text { Lithotamnium limestone }\end{array}$ & $\begin{array}{l}\text { haplic arenosol, haplic } \\
\text { luvisol }\end{array}$ & Thermophilous oak forests \\
\hline Kisielany & $\begin{array}{l}52^{\circ} 15^{\prime} 12^{\prime \prime} \\
22^{\circ} 12^{\prime} 26^{\prime \prime}\end{array}$ & 146 & $\begin{array}{c}\text { outwash sands and gravels, } \\
\text { clays }\end{array}$ & stagnic retisol & Thermophilous oak forests \\
\hline \multicolumn{6}{|c|}{ Romania } \\
\hline Herculian & $\begin{array}{l}46^{\circ} 07^{\prime} 05^{\prime \prime} \\
25^{\circ} 42^{\prime} 38^{\prime \prime}\end{array}$ & 635 & volcanic sediments & $\begin{array}{l}\text { andosols, chernozem, } \\
\text { kastanozem }\end{array}$ & $\begin{array}{l}\text { Central Europ. basiphilous } \\
\text { thermophilous oak forest }\end{array}$ \\
\hline Prejmer & $\begin{array}{l}45^{\circ} 43^{\prime} 59^{\prime \prime} \\
25^{\circ} 44^{\prime} 20^{\prime \prime}\end{array}$ & 518 & quaternary sediments & $\begin{array}{l}\text { histosol, stagnosol, } \\
\text { fluvisol }\end{array}$ & Intermittently wet Molinia meadows \\
\hline \multicolumn{6}{|c|}{ Slovakia } \\
\hline Cigánka & $\begin{array}{l}48^{\circ} 45^{\prime} 49^{\prime \prime} \\
20^{\circ} 03^{\prime} 43^{\prime \prime}\end{array}$ & 825 & dolomitical rocks & podzolic cambisol & Limestone beech forest \\
\hline
\end{tabular}




\begin{tabular}{|c|c|c|c|c|c|}
\hline Site & $\begin{array}{l}\text { Latitude } \\
\text { Longitude }\end{array}$ & $\begin{array}{l}\text { Alt. } \\
(\mathrm{m})\end{array}$ & Bedrock & $\begin{array}{c}\text { Soil } \\
\text { (acc. to WRB 2014) }\end{array}$ & Habitat acc. o EH Habitat Directive \\
\hline Kopanec & $\begin{array}{l}48^{\circ} 54^{\prime} 54^{\prime \prime} \\
20^{\circ} 17^{\prime} 16^{\prime \prime}\end{array}$ & 850 & sandy and gravelly sediments & $\begin{array}{c}\text { cambisol, litosol rubble } \\
\text { rendzina }\end{array}$ & Limestone beech forest \\
\hline Michalovo & $\begin{array}{l}49^{\circ} 00^{\prime} 43^{\prime \prime} \\
19^{\circ} 45^{\prime} 05^{\prime \prime}\end{array}$ & 1136 & dolomitical rocks & $\begin{array}{l}\text { cambisol, carbonate } \\
\text { litosol }\end{array}$ & $\begin{array}{l}\text { Limestone beech forest, relict pine forest } \\
\text { on limestone }\end{array}$ \\
\hline Pusté pole - E & $\begin{array}{l}48^{\circ} 53^{\prime} 05^{\prime \prime} \\
20^{\circ} 14^{\prime} 50^{\prime \prime}\end{array}$ & 914 & sandy and gravelly sediments & $\begin{array}{l}\text { cambisol, litosol rubble } \\
\text { rendzina }\end{array}$ & Limestone beech forest \\
\hline Pusté pole $-\mathrm{W}$ & $\begin{array}{l}48^{\circ} 53^{\prime} 16^{\prime \prime} \\
20^{\circ} 13^{\prime} 44^{\prime \prime}\end{array}$ & 990 & sandy and gravelly sediments & $\begin{array}{l}\text { cambisol, litosol rubble } \\
\text { rendzina }\end{array}$ & Limestone beech forest \\
\hline Silica & $\begin{array}{l}48^{\circ} 34^{\prime} 27^{\prime \prime} \\
20^{\circ} 33^{\prime} 12^{\prime \prime}\end{array}$ & 596 & light steinalm limestones & $\begin{array}{l}\text { histosol, stagnosol, } \\
\text { fluvisol }\end{array}$ & Intermittently wet Molinia meadows \\
\hline Suchá Belá & $\begin{array}{l}48^{\circ} 57^{\prime} 18^{\prime \prime} \\
20^{\circ} 22^{\prime} 46^{\prime \prime}\end{array}$ & 680 & sandy and gravelly sediments & $\begin{array}{l}\text { cambisol, litosol rubble } \\
\text { rendzina }\end{array}$ & Limestone beech forest \\
\hline Trsteník & $\begin{array}{l}48^{\circ} 48^{\prime} 36^{\prime \prime} \\
20^{\circ} 07^{\prime} 53^{\prime \prime}\end{array}$ & 860 & sandy and gravelly sediments & $\begin{array}{l}\text { histosol, stagnosol, } \\
\text { fluvisol }\end{array}$ & $\begin{array}{c}\text { Montane Alnus incana galeries, } \\
\text { Alder swamp wood }\end{array}$ \\
\hline
\end{tabular}

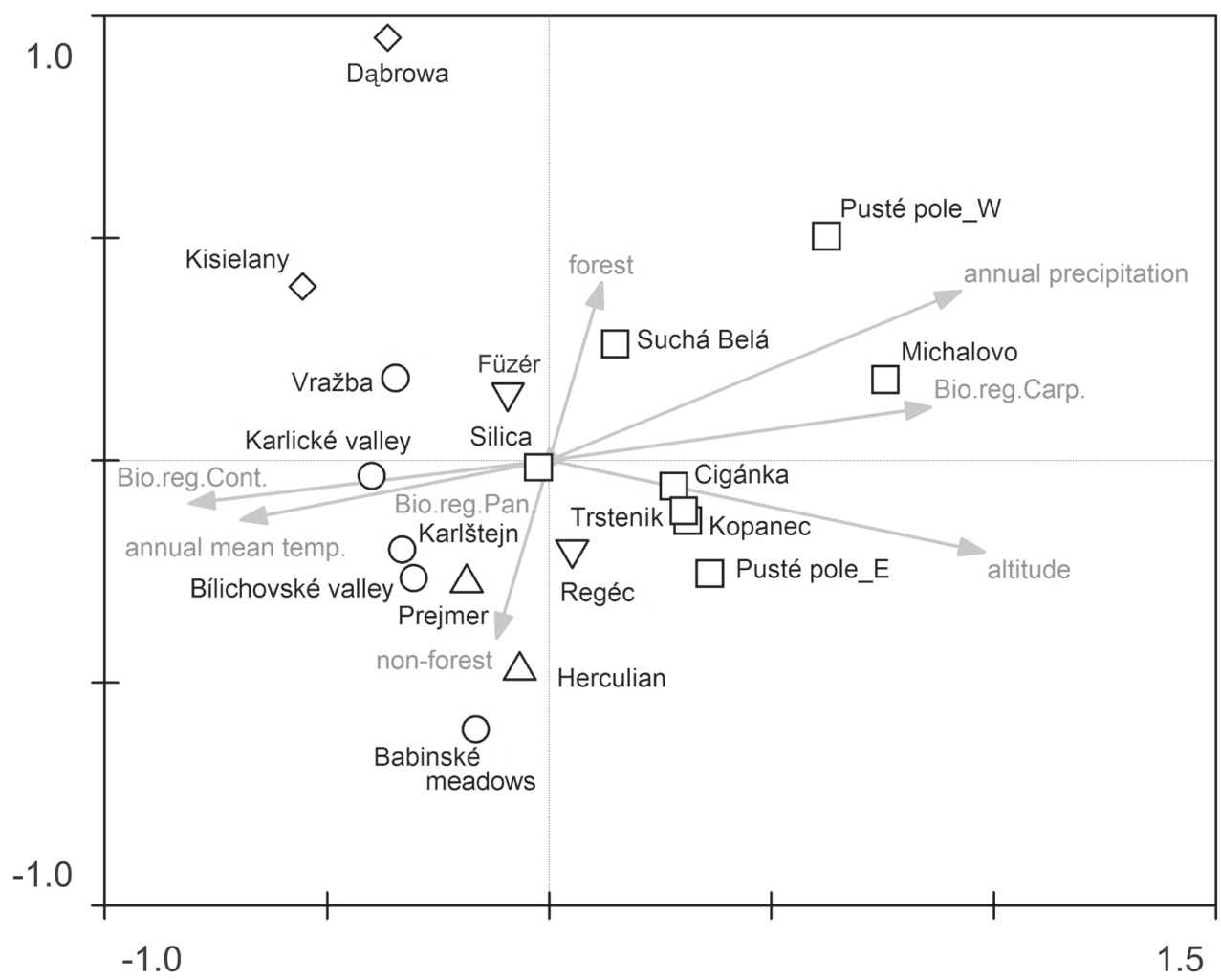

Fig. 2. Ordination diagram of the studied A. liliifolia localities based on PCA analysis. Czech Republic - circle, Slovakia - square, Romania - up-triangle, Poland - diamond and Hungary - down-triangle. The first two axes explained $92 \%$ of the total variability. Bio. Reg.: Cont., Carp., Pan - biogeographical region in Europe: Continental, Carpathian, Panonian. 
CHARACTERISTICS OF A. LILIIFOLIA HABITATS

The vegetation type in which A. liliifolia occurred was assessed using 43 phytosociological relevés from the surveyed population in Czechia (19 rel.), Poland (6 rel.), Slovakia (10 rel.), and Romania (8 rel.), 29 published relevés from Poland (7 rel.) by Ciosek (2006), from Hungary (20 rel.) by Farkas and Vojtkó (2012), and from Romania (2 rel.) by Indreica (2011), and 32 relevés from the TuRBOvEG database for Czechia (Working Group for Vegetation Science, 2011; 3 rel.) and Slovakia (Working Group on Vegetation Research, 2012; 29 rel.). The nomenclature of the plant communities corresponds to that used in Chytrý $(2007,2013)$. The cover and the abundance of species was evaluated in the 9-grade Braun-Blanquet scale (Braun-Blanquet, 1964; Working Group for Vegetation Science, 2011). A synoptic table was made in Juice 7 (Tichý, 2011) using the frequency percentage of a particular species. Only diagnostic species with a fidelity $\geq 75 \%$, constant species with a frequency $\geq 70 \%$, and dominant species with a cover treshold $\geq 25 \%$ are shown in Tab. 4. For each relevé, Ellenberg values for continentality $(\mathrm{C})$, light $(\mathrm{L})$, moisture $(\mathrm{F})$, nutrient $(\mathrm{N})$, soil reaction $(\mathrm{R})$, and temperature $(\mathrm{T})$ were excerpted using Juice 7 (Tichý, 2011). Ellenberg indicator values were used to characterize the site conditions of 6 determined vegetation units in the STATISTICA 12 program (StatSoft, 2015).

\section{GENETIC ANALYSES}

Plant material and DNA extraction. A total of 84 samples collected from 23 localities from five European countries (Tab. 5) were used for the genetic analyses. Each sample was represented by two leaves taken from one stem of a randomly selected tuft at each locality, and immediately preserved in plastic bags with silica gel until DNA extraction could be performed. Genomic DNA was extracted using a modified CTAB protocol (Doyle and Doyle, 1987). The integrity and quality of the extracted DNA was estimated using $1.5 \%$ agarose gel. The DNA concentrations were determined using a NanoDrop ND-1000 Spectrophotometer (NanoDrop Technologies, Delaware, USA).

AFLP analysis. AFLP analysis was carried out according to the procedure of Vos et al. (1995), with modifications according to Kitner et al. (2008). In total, eight selective primer combinations were chosen to generate the AFLP profiles (Tab. 2). The amplification products were separated on $6 \%, 0.4 \mathrm{~mm}$-thick denaturing polyacrylamide gels $(0.5 \times \mathrm{TBE}$ buffer $)$ using a T-REX sequencing gel electrophoresis apparatus (Thermo Scientific Owl Separation Systems, Rochester, NY, USA). As a size standard, 30-330-bp AFLP® DNA Ladder (Thermo Fischer Scientific) was used. Silver staining was used to detect the AFLP fragments after electrophoretic separation.

TABLE 2. Primers and primer sets for preamplification and amplification reactions with the total number of scored (NB) and polymorphic bands (NPB).

\begin{tabular}{|c|c|c|c|}
\hline \multicolumn{4}{|c|}{ Preamplification Primers Sequence } \\
\hline \multicolumn{4}{|c|}{ EcoRI 5' - G ACT GCG TAC CAA TTC A - 3' } \\
\hline \multicolumn{4}{|c|}{ MseI 5’ - G ATG AGT CCT GAG TAA C - 3' } \\
\hline & Amplification Primer Sets Sequences & $\mathrm{N}_{\mathrm{B}}$ & $\mathrm{N}_{\mathrm{PB}}$ \\
\hline Set A & EcoRI primer E-GG / MseI primer M-AAC & 41 & 31 \\
\hline Set B & EcoRI primer E-CC / MseI primer M-AAC & 43 & 38 \\
\hline Set C & EcoRI primer E-CC / MseI primer M-AAT & 49 & 44 \\
\hline Set D & EcoRI primer E-CG / MseI primer M-AAC & 35 & 29 \\
\hline Set $\mathrm{E}$ & EcoRI primer E-CG / MseI primer M-AAT & 42 & 36 \\
\hline Set $F$ & EcoRI primer E-TCG / MseI primer M-AACG & 22 & 17 \\
\hline Set $\mathrm{G}$ & EcoRI primer E-TCC / MseI primer M-AACG & 26 & 20 \\
\hline Set $\mathrm{H}$ & EcoRI primer E-TC / MseI primer M-AACCG & 33 & 27 \\
\hline total & & 291 & 242 \\
\hline
\end{tabular}




\section{DATA ANALYSIS}

To check the reliability of the AFLP analysis, the amplification for each primer combination with the whole sample set and, additionally, the amplification of randomly chosen samples (from two to three samples per each population) was repeated. The AFLP profiles were checked visually, and only clear and unambiguous bands were scored for their presence (1) or absence (0). In the last step, the results of scoring were compared and checked for the number of markers, intensity of the markers, and relative position of the markers. In the final binary matrix only verified markers (present in the original and repeated amplification) were used. The error rate was calculated as the difference in the total number and the number of fragments used in the final matrix. In order to determine whether genetic subpopulations can be detected in the analyzed sample set, the Bayesian approach was used as implemented in STRUCtURE 2.2 (Falush et al., 2007). Computation in STRUCTURE was set up for the recessive allele model and the admixture model with correlated allele frequencies. The $K$ was set to $1-10$ with 10 replicate runs for each $K$ using the $1,000,000$ MCMC iterations following the period of 100,000 burn-in iterations. For the graphical interpretation of clustering for the appropriate $K$, STRUCTURE HARVESTER (Earl and von Holdt, 2012), ClumpP (Jacobsson and Rosenberg, 2007), and Distruct (Rosenberg, 2004) software were used. For the further visualization of the population genetic structure and relationships among individuals a Neighbor-joining (NJ) dendrogram was constructed [based on the Dice coefficient of similarity, 1,000 bootstrap replicates (Felsenstein, 1985)] using FREeTREe software (Pavlíček et al., 1999), and the resulting tree was visualised and arranged in FigTree v1.4.0 software (FigTree, 2015). The statistical indices for polymorphism (P\%) and Shannon's Information Index (I) were performed using GenAlex 6 software (Peakall and Smouse, 2006). The number of private bands $\left(\mathrm{N}_{\mathrm{PB}}\right.$; a band unique for a given population, but not for all individual), and the number of fixed private bands $\left(\mathrm{N}_{\mathrm{FPB}}\right.$; the number of bands common for all individuals within a single population) were calculated in FAMD 1.31 (Schlüter and Harris, 2006). The ARLEQUiN 3.5 (Excoffier and Lischer, 2010) was used for calculating the analysis of molecular variance (AMOVA) to inspect the partitioning and significance of the genetic variation distribution among and within the analyzed populations. AFLPdat (Ehrich, 2006) was used for the calculation of DW or "frequency-down-weighted marker" values according to Schönswetter and Tribsch (2005). DW values were used as a standardized measure of divergence and identification of long-term isolation. For the calcu- lation of DW values no adjustment for the number of individiuals was made, and DW values were calculated for all of the individuals within each population. AFLP-SURV 1.0 (Vekemans, 2002) (square root method) was used to assess the gene diversity under Hardy-Weinberg genotypic proportions $(\mathrm{Hj})$, also called Nei's gene diversity, the total gene diversity (Ht), and fixation index $\left(\mathrm{F}_{\mathrm{ST}}\right)$. Correlation and regression analyses (to check the relationship between the obtained indices, population sizes, i.e., numbers of tufts and generative ramets), were computed in MS Excel add-in XLSTAT 2015 (Addinsoft, 2015), as well as the Mantel test to explore the hypothesis of isolation by distance (IBD) by examining the correlation between the matrices representing Fst/(1-Fst) and the natural logarithm of geographic distance (ln d) for pairs of subpopulations (10.000 permutations). The regression analysis was also performed to provide the information about the linkage of the geographic position of localities (longitude) with polymorphism and gene diversity.

\section{RESULTS}

\section{THE CURRENT CONDITION \\ OF A. LILIIFOLIA POPULATIONS}

With respect to the population size in particular localities (number of tufts, number of fertile and sterile stems, and average number of stems in a tuft) the data are shown in Tab. 3. All of the Slovak localities (except for Michalovo and Silica) show a strong similarity based on a higher altitude, higher average annual precipitation, and A. liliifolia occurrence in forest vegetation units. Thus these localities represent a distinct group among other investigated localities (Fig. 2). The Romanian and the majority of the Czech localities are similar to one another. These localities represent non-forest habitats, or forest ecotones with higher than average annual temperatures. The Karlické valley and Vražba (CZ) are different, and their characteristics are close to the localities in Poland (Kisielany, Dąbrowa) and Hungary (Füzér, Regéc). Two localities - Babínské meadows (CZ) and Silica (SK) represent non-forest localities with higher average annual temperatures in comparison with the other localities.

\section{VEGETATION IN A. LILIIFOLIA LOCALITIES}

The linkage between A. liliifolia occurence and the type of vegetation present in the locality can be seen in the synoptic table (Tab. 4). According to the analysis of all the recorded and published relevés (Ciosek, 2006; Farkas and Vojtkó, 2012; Indreica, 2011), six vegetation units in recent and historic 
TABLE 3. Threat categories according to Red Lists of particular countries (CR - critically endangered, EN - endangered, VU - vulnerable), size of populations, morphological characteristics and number of species in phytosociological relevés in locality.

\begin{tabular}{|c|c|c|c|c|c|c|c|c|c|c|c|}
\hline \multirow[b]{2}{*}{ Locality } & \multirow[b]{2}{*}{$\begin{array}{l}\text { Threat } \\
\text { in } \\
\text { country }\end{array}$} & \multicolumn{4}{|c|}{ Size of population } & \multicolumn{5}{|c|}{ Morphological characteristics } & \multirow[b]{2}{*}{$\begin{array}{c}\text { Number } \\
\text { of species } \\
\text { in } \\
\text { a relevé }\end{array}$} \\
\hline & & Tufts & Stems & $\begin{array}{c}\% \\
\text { fertile } \\
\text { stems }\end{array}$ & $\begin{array}{c}\text { Average } \\
\text { number of } \\
\text { stems/span } \\
\text { in one tuft }\end{array}$ & $\begin{array}{l}\text { Average } \\
\text { hight } \\
(\mathrm{cm})\end{array}$ & $\begin{array}{l}\text { Average } \\
\text { number } \\
\text { of } \\
\text { leaves }\end{array}$ & $\begin{array}{c}\text { Average } \\
\text { ratio length/ } \\
\text { width leaf }\end{array}$ & $\begin{array}{c}\text { Average } \\
\text { number } \\
\text { of flowers/ } \\
\text { infloresc. }\end{array}$ & $\begin{array}{l}\text { Average } \\
\text { number of } \\
\text { branches/ } \\
\text { infloresc. }\end{array}$ & \\
\hline \multicolumn{12}{|c|}{ Czechia } \\
\hline $\begin{array}{l}\text { Babínské } \\
\text { meadows }\end{array}$ & $\mathrm{CR}$ & 20 & 44 & 72.7 & $2.2 / 1-15$ & 43 & 19.95 & 3.6 & 8.13 & 2.88 & $41-53$ \\
\hline $\begin{array}{l}\text { Bílichovské } \\
\text { valley }\end{array}$ & $\mathrm{CR}$ & 26 & 23 & 13 & $1.4 / 1-7$ & 64.44 & 36.56 & 3.5 & 24.67 & 4.33 & $21-29$ \\
\hline Karlické valley & $\mathrm{CR}$ & 22 & 26 & 23.1 & $1.2 / 1-3$ & 33.5 & 19.44 & 2.7 & 5.33 & 0 & $58-60$ \\
\hline Karlštejn & $\mathrm{CR}$ & 22 & 63 & 84.1 & $2.9 / 1-6$ & 91.78 & 36.37 & 3.2 & 46.89 & 9.68 & $38-81$ \\
\hline Vražba & $\mathrm{CR}$ & 83 & 200 & 96.5 & $2.4 / 1-14$ & 98.04 & 32.71 & 3.5 & 48.18 & 9.34 & $38-64$ \\
\hline \multicolumn{12}{|c|}{ Hungary } \\
\hline Füzér & EN & 18 & 22 & 31.8 & $1.2 / 1-2$ & 34.42 & 19.7 & 2.6 & 16 & 3.33 & $30-42$ \\
\hline Regéc & EN & 38 & 62 & 17.7 & $1.6 / 1-4$ & 26.08 & 15.97 & 2.3 & 4.9 & 0.5 & $16-49$ \\
\hline \multicolumn{12}{|c|}{ Poland } \\
\hline Dąbrowa & $\mathrm{EN}$ & 53 & 76 & 73.7 & $1.4 / 1-8$ & missi & ing data & & & & $39-58$ \\
\hline Kisielany & EN & 1000 & 1500 & 66.7 & $1.5 / 1-11$ & 148.7 & 48 & 3.9 & 54 & 12 & $41-56$ \\
\hline \multicolumn{12}{|c|}{ Romania } \\
\hline Herculian & VU & 9 & 18 & 22.2 & $2 / 1-5$ & 48.83 & 24.05 & 4.3 & 10.75 & 4.29 & $31-42$ \\
\hline Prejmer & VU & 13 & 98 & 63.3 & $7.5 / 1-14$ & 70.72 & 33.09 & 3.6 & 40.23 & 10.52 & $34-49$ \\
\hline \multicolumn{12}{|c|}{ Slovakia } \\
\hline Cigánka & EN & 440 & 552 & 56.2 & $1.3 / 1-3$ & 58.46 & 30.18 & 3.6 & 24.65 & 6.55 & $36-54$ \\
\hline Kopanec & EN & 8 & 15 & 100 & $1.8 / 1-3$ & 85.2 & 33 & 3.1 & 18.5 & 3.1 & $49-54$ \\
\hline Michalovo & EN & 61 & 210 & 55.7 & $2.2 / 1-4$ & 67.73 & 27.64 & 2.6 & 23.78 & 6.67 & $51-58$ \\
\hline Pusté pole - E & EN & 5 & 7 & 100 & $1.4 / 1-2$ & 75.8 & 31 & 3.5 & 20 & 2.5 & $27-36$ \\
\hline Pusté pole - W & EN & 41 & 96 & 70.8 & $2.3 / 1-5$ & 83.78 & 34.31 & 4.5 & 38.4 & 8.92 & $49-53$ \\
\hline Silica & EN & 38 & 60 & 11.7 & $1.6 / 1-5$ & 44.83 & 21.34 & 3.4 & 14.75 & 4.8 & $36-43$ \\
\hline Suchá Belá & $\mathrm{EN}$ & 7 & 7 & 100 & $1 / 1-1$ & 72.1 & 27 & 3.3 & 14.8 & 2.6 & $50-80$ \\
\hline Trstenik & EN & 343 & 474 & 49.8 & $1.4 / 1-6$ & 93.37 & 27.93 & 3.6 & 31 & 7.64 & $47-57$ \\
\hline
\end{tabular}

localities of $A$. liliifolia were distinguished: 1) intermittently wet Molinia meadows (alliance Molinion caeruleae W. Koch 1926), 2) thermophilous oak forests (association Potentillo albae-Quercetum Libb. 1933), also Kiskőrös (HU), which is located in transition to alluvial forests, was ranked into this unit, 3) Central European basiphilous thermophilous oak forests (alliance Quercion pubescenti-petraeae Klika 1933 corr. Moravec in Beg. et Theurill 1984), 4) oak-hornbeam forests (association Tilio cordatae-Carpinetum betuli Tracz. 1962), 5) limestone beech forests (association 
TABLE 4. Synoptic table with 6 clusters using percentage frequency of species in the vegetation unit. Vegetation units: 1 - intermittently wet Molinia meadows, 2 - thermophilous oak forests (association Potentillo albae-Quercetum), 3 - Central European basiphilous thermophilous oak forests (alliance Quercion pubescenti-petraeae), 4 - oak-hornbeam forests (association Tilio-Carpinetum), 5 - limestone beech forests (association Cephalanthero-Fagetum), 6 - mosaic of montane Alnus incana galleries and alder swamp wood on basic and neutral substrate included in Alnion incanae alliance. Percentage of $70 \%$ and above in bold, except for unit 6 column, where percentage 100\% in bold (only 2 relevés).

\begin{tabular}{ccccccccc}
\hline \hline Vegetation unit & 1 & 2 & 3 & 4 & 5 & 6 \\
\hline Number of relevés & 24 & 22 & 8 & 19 & 30 & 2
\end{tabular}

E3

Quercus robur 50

Carpinus betulus 32

Quercus virgiliana

63

Quercus petraea

16

Fagus sylvatica

26

50

Abies alba

16

57

Alnus incana

100

Salix pentandra

E2

Cornus mas

Viburnum lantana

Quercus petraea

Corylus avellana

Crataegus sp.

Frangula alnus

Alnus incana

Salix pentandra

E1

Adenophora liliifolia

100

Betonica officinalis

Molinia caerulea s.l.

Convallaria majalis

Lathyrus niger

Carex montana

Melittis melissophyllum

Melica nutans

Brachypodium sylvaticum

Carex digitata

Aegopodium podagraria
83

21

4

8

17

\section{3}

33

4

25

4

73

4

4
75

5

75

11

74

3

13

74

13

64

13

5

7

100

68

18

86

77

77

50

63

80

$\begin{array}{lll}77 & 50 & 53\end{array}$

$25 \quad 77$

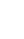

73

13

58

13

64

25

89

57

50

38

74

74

57

14

74

3

100

14

4


TABLE 4.

\begin{tabular}{|c|c|c|c|c|c|c|}
\hline Vegetation unit & 1 & 2 & 3 & 4 & 5 & 6 \\
\hline Number of relevés & 24 & 22 & 8 & 19 & 30 & 2 \\
\hline Asarum europaeum & & 5 & & 84 & 23 & \\
\hline Hepatica nobilis & & 5 & & 89 & & \\
\hline Pulmonaria obscura & & 5 & & 79 & & \\
\hline Calamagrostis varia & & & & & 83 & 100 \\
\hline Galium schultesii & & 41 & 25 & 16 & 83 & \\
\hline Pimpinella major & 29 & & & 21 & 70 & \\
\hline Laserpitium latifolium & & 45 & & & 80 & \\
\hline Rubus saxatilis & & 14 & & & 87 & \\
\hline Cirsium erisithales & & & & & 77 & \\
\hline Carduus crassifolius ssp. glaucus & & & & & 70 & \\
\hline Cruciata glabra & 54 & 9 & 38 & 5 & 7 & 50 \\
\hline Ajuga reptans & 25 & 59 & & 58 & 3 & 100 \\
\hline Angelica sylvestris & 8 & 41 & & 5 & 13 & 100 \\
\hline Astrantia major & 54 & 55 & & 37 & 40 & 100 \\
\hline Lathyrus pratensis & 38 & 5 & & 5 & 7 & 100 \\
\hline Trollius europaeus & 17 & 14 & & & 3 & 100 \\
\hline Colchicum autumnale & 38 & 5 & & & & 50 \\
\hline Succisa pratensis & 42 & 14 & & & 3 & 100 \\
\hline Carex umbrosa & 13 & 9 & & & 3 & 50 \\
\hline Deschampsia cespitosa & 4 & 5 & & 21 & & 100 \\
\hline Leontodon hispidus & 33 & & & & 17 & 50 \\
\hline Thalictrum aquilegiifolium & 4 & 27 & & & & 100 \\
\hline Listera ovata & & 9 & & & 7 & 100 \\
\hline Tanacetum clusii & & & & & 53 & 100 \\
\hline Gentiana asclepiadea & & & & & 50 & 100 \\
\hline Cirsium oleraceum & & & & 37 & & 100 \\
\hline Carex paniculata & 17 & & & & & 100 \\
\hline Carex panicea & 8 & & & & & 50 \\
\hline Equisetum palustre & 8 & & & & & 100 \\
\hline Gymnadenia conopsea & 8 & & & & & 100 \\
\hline Filipendula ulmaria & 4 & & & & & 100 \\
\hline Galium palustre & 4 & & & & & 50 \\
\hline Knautia maxima & & & & & 10 & 100 \\
\hline
\end{tabular}


TABLE 4.

\begin{tabular}{|c|c|c|c|c|c|c|}
\hline Vegetation unit & 1 & 2 & 3 & 4 & 5 & 6 \\
\hline Number of relevés & 24 & 22 & 8 & 19 & 30 & 2 \\
\hline Centaurea pseudophrygia & & & & & 3 & 100 \\
\hline Carex davalliana & & & & & & 50 \\
\hline Carex flava & & & & & & 100 \\
\hline Valeriana simplicifolia & & & & & & 100 \\
\hline \multicolumn{7}{|l|}{ Juv. } \\
\hline Acer campestre & & 5 & 38 & 79 & & \\
\hline Alnus incana & & & & & & 100 \\
\hline \multicolumn{7}{|l|}{ EO } \\
\hline Hylocomium splendens & 4 & & & & 27 & 100 \\
\hline Rhytidiadelphus sp. & & & & & 17 & 100 \\
\hline Aulacomnium palustre & & & & & & 100 \\
\hline Climacium dendroides & & & & & & 100 \\
\hline
\end{tabular}

Cephalanthero-Fagenion R. Tx. 1955), 6) mosaic of montane Alnus incana galleries, montane fens with Swertia perennis from the Caricion davallianae Klika 1934 alliance and alder swamp wood on basic and neutral substrate included in the Alnenion glutinoso-incanae Oberd. 1953 alliance (Tab. 4).

\section{SITE CONDITIONS OF THE A. LILIIFOLIA LOCALITIES}

Site conditions of the six distinguished vegetation units with the presence of A. liliifolia were compared using Ellenberg's indicators (Ellenberg et al., 1992) for nutrients, soil reaction, temperature, light, moisture, and continentality (Fig. 3). When comparing the ecological demands of A. liliifolia according to Ellenberg et al. (1992) with the ecological conditions calculated from the phytosociological relevés using Ellenberg indicators (Fig. 3), we can say that the current optimal vegetation units for this species in Central Europe are Central European basiphilous thermophilous oak forests (alliance Quercion pubescenti-petraeae) and intermittently wet Molinia meadows. The light-, temperature-, moisture-, and soil reaction values calculated in these vegetation units are the most similar to the ecological demand of A. liliifolia. While intermittently wet Molinia meadows offer the most convenient conditions with respect to light, continentality, and moisture, Central European basiphilous thermo- philous oak forests are most suitable for A. liliifolia with respect to temperature and soil reaction. Low moisture can be a limiting factor for this species in Central European basiphilous thermophilous oak forests. According to Ellenberg et al. (1992), the optimal value for nutrients is 2 , but in all localities, this value was 3-6. Central European basiphilous thermophilous oak forests, which are comparatively the most convenient vegetation unit concerning nutrients, have the second widest amplitude with respect to this factor. The worst conditions for A. liliifolia were found in oak-hornbeam forests (association Tilio cordatae-Carpinetum betuli), limestone beech forests (association Cephalanthero damassonii-Fagetum sylvaticae Oberdorfer 1957), and mosaic of montane Alnus incana galleries and alder swamp wood, mainly because of low light intensity and temperature. In these habitats, A. liliifolia can only grow thanks to disturbances and management directed to an open forest.

Adenophora liliifolia shows a high morphological variability related to the geological bedrock, soil, moisture, and habitat in which it grows (Tab. 3). The investigated localities showed differences in species alpha-diversity. The most species-rich were two Czech localities (Vražba and Karlštejn) and three Slovak localities (Malý Sokol, Suchá Belá, and Michalovo). The fewest number of species were recorded in the Hungarian locality Regéc and in the Czech locality Bílichovské valley (Tab. 3). 


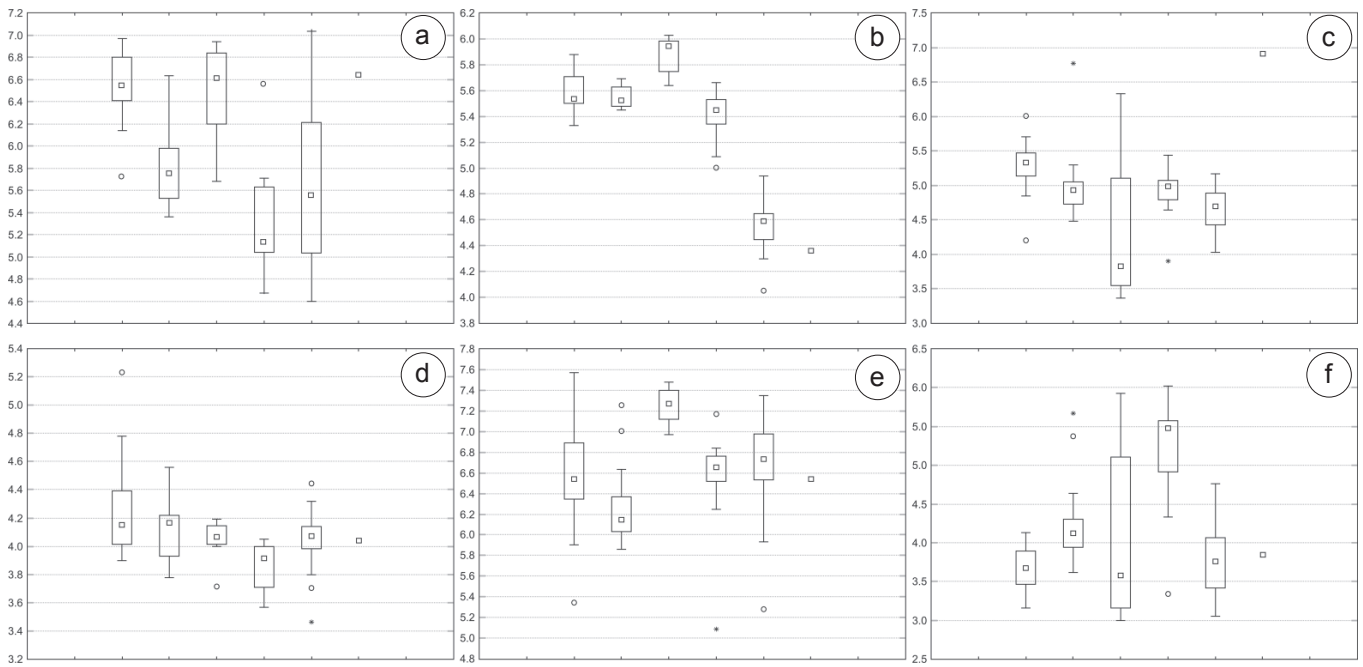

Fig. 3. Comparison of 6 vegetation units (in this order: 1. Molinion caeruleae, 2. Potentillo albae-Quercetum, 3. Quercion pubescenti-petraeae, 4. Carpinion betuli, 5. Cephalanthero damassonii-Fagetum sylvaticae, 6. Alnenion glutinoso-incanae) based on used releves by means of Ellenberg indicator values (a) light, (b) temperature, (c) moisture, (d) continentality, (e) soil reaction, (f) nutrients).

\section{MANAGEMENT IN A. LILIIFOLIA LOCALITIES}

Adenophora liliifolia populations in Czechia are negatively influenced by many factors (e.g., overpopulated wild animals, inappropriate forest management, global eutrophication, expansive herbs, young trees, parasitic insects, and fungi). All Czech populations growing in forests, if not protected by fences against grazing, were browsed by overpopulated hoofed game. The level of grubbing out with respect to the underground organs was found to be increasing, especially in oak-hornbeam forests located at Karlštejn in Český kras PLA (Protected Landscape Area). The population in the Babinské meadows was negatively influenced not only by grazing and grubbing out, but also by expansion of Calamagrostis epigejos (L.) Roth. Rubus L. expansion also impacts A. liliifolia populations, mainly in oak-hornbeam forests. Not only the Czech localities, but also Trsteník in the Muránska planina NP (National park) in Slovakia and both of the Polish localities studied are affected by inappropriate forest management. Several Czech localities (Vražba, Bílichovské valley, and Karlštejn) have special management regulations protecting $A$. liliifolia against grazing by fences and against competitive vascular plants by cutting. Sheep pasturing occurs at the Silická planina in Slovenský kras NP (Silica, SK), and the A. liliifolia present at Silica is intensively grazed every year before it creates flowers and seeds. The most stable habitat for A. liliifolia populations is the limestone beech forest in the locality of Michalovo in Nízke Tatry NP. The plants grow there in slightly shaded parts of the forest, often on rocky bedrock. They are rarely influenced by grazing, grubbing out, or by human activities, and their seeds have enough space for germination. The other localities (Slovenský raj NP, Muránska planina NP, Slovenský kras NP, Czech, Romanian, and Hungarian localities) are affected by grazing and grubbing out by wildlife.

\section{GENETIC VARIABILITY}

A total of 84 A. liliifolia plants from 23 populations were analyzed using eight AFLP primer combinations (Tab. 2), which generated 291 bands, of which 242 were polymorphic (83.2\%). Replication of the analysis revealed high reliability of AFLP, with an error rate of $2.4 \%$. Statistical indices (Tab. 5) were not computed for four localities which were represented by one or two samples. The highest values for Nei's gene diversity $(\mathrm{Hj})$ were observed for samples from Kopanec $(\mathrm{Hj}=0.171)$ and Pusté pole-E $(\mathrm{Hj}=166)$, both located in Slovakia. The lowest value was observed for the Czech population from Karlštejn $(\mathrm{Hj}=105)$. We recorded only a single fixed private band unique for populations located in Silica (SK) which was present among all of the sampled localities. The values for the DW index ranged from 1.7 to 4.2 . The highest indices (DW $=4.2$ ) were observed for the Slovak populations located at Suchá Belá and Pusté pole E, followed by the Hungarian locality at Ocsa (DW = 3.9). The lowest values were recorded for the Czech populations at Karlštejn (DW $=1.8$ ) and the Bílichovké valley $(\mathrm{DW}=1.7)$. The computation of Shannon's Information Index produced the lowest value for the 
TABLE 5. List of analysed samples with population genetic statistics (n, number of samples; $\mathrm{N}_{\mathrm{PB}}$, number of private bands; $\mathrm{N}_{\mathrm{FPB}}$, number of fixed private bands; P\%, polymorphism; I, Shannon's Information Index; $\mathrm{Hj}$, Nei's gene diversity; $\mathrm{DW}$, frequency down - weighed marker value; SE, sum of errors)

\begin{tabular}{|c|c|c|c|c|c|c|c|c|}
\hline Site & ID of samples & $\mathrm{n}$ & $\mathrm{N}_{\mathrm{PB}}$ & $\mathrm{N}_{\mathrm{FPB}}$ & $\mathrm{P} \%$ & I (SE) & $\mathrm{Hj}(\mathrm{SE})$ & DW \\
\hline Czechia & & 18 & 2 & 0 & 56.1 & $0.194(0.013)$ & $0.128(0.009)$ & 2.3 \\
\hline Babínské meadows & $1-4$ & 4 & 0 & 0 & 28.2 & $0.142(0.014)$ & $0.137(0.010)$ & 2.8 \\
\hline Bílichovské valley & $5-8$ & 4 & 0 & 0 & 25.9 & $0.131(0.014)$ & $0.127(0.010)$ & 1.7 \\
\hline Karlické valley & $9-10$ & 2 & - & - & - & - & - & - \\
\hline Karlštejn & $11-13$ & 3 & 0 & 0 & 18.5 & $0.087(0.012)$ & 0.105 (0.009) & 1.8 \\
\hline Vražba & $14-18$ & 5 & 2 & 0 & 32.4 & $0.154(0.014)$ & $0.137(0.010)$ & 2.8 \\
\hline Hungary & & 21 & 5 & 0 & 64.4 & $0.229(0.013)$ & $0.149(0.009)$ & 3.II \\
\hline Aggtelek & 19 & 1 & - & - & - & - & - & - \\
\hline Dabas & $20-21$ & 2 & - & - & - & - & - & - \\
\hline Füzér & $22-26$ & 5 & 0 & 0 & 28.2 & $0.148(0.015)$ & $0.137(0.011)$ & 3.0 \\
\hline Kiskőrös & $27-31$ & 5 & 0 & 0 & 31.7 & $0.148(0.014)$ & $0.132(0.009)$ & 3.3 \\
\hline Ocsa & $32-34$ & 3 & 0 & 0 & 24.2 & $0.122(0.013)$ & $0.148(0.010)$ & 3.9 \\
\hline Regéc & $35-39$ & 5 & 0 & 0 & 37.2 & $0.177(0.014)$ & $0.152(0.010)$ & 3.0 \\
\hline Poland & & 6 & 0 & 0 & 38.6 & $0.167(0.014)$ & $0.132(0.009)$ & 2.3 \\
\hline Dąbrowa & 40 & 1 & - & - & - & - & - & - \\
\hline Kisielany & $41-45$ & 5 & 0 & 0 & 36.2 & $0.168(0.014)$ & $0.141(0.010)$ & 2.6 \\
\hline Romania & & 10 & 1 & 0 & 48.2 & $0.181(0.013)$ & $0.128(0.009)$ & 3.1 \\
\hline Herculian & $46-50$ & 5 & 0 & 0 & 37.8 & $0.157(0.014)$ & $0.133(0.010)$ & 2.9 \\
\hline Prejmer & 51-55 & 5 & 0 & 0 & 32.1 & $0.150(0.014)$ & $0.131(0.009)$ & 3.5 \\
\hline Slovakia & & 29 & 14 & 0 & 68.8 & $0.229(0.013)$ & $0.144(0.009)$ & 3.1 \\
\hline Cigánka & $56-60$ & 5 & 0 & 0 & 29.6 & $0.144(0.014)$ & $0.127(0.010)$ & 2.3 \\
\hline Kopanec & 61-63 & 3 & 0 & 0 & 25.4 & $0.161(0.015)$ & $0.171(0.011)$ & 3.2 \\
\hline Michalovo & 64-68 & 5 & 0 & 0 & 30.3 & $0.138(0.013)$ & $0.122(0.009)$ & 2.5 \\
\hline Pusté pole $-\mathrm{E}$ & 69-71 & 3 & 0 & 0 & 26.5 & $0.146(0.015)$ & $0.166(0.011)$ & 4.2 \\
\hline Pusté pole - W & $72-74$ & 3 & 0 & 0 & 18.9 & $0.106(0.013)$ & $0.131(0.010)$ & 3.3 \\
\hline Silica & $75-78$ & 4 & 1 & 1 & 20.6 & $0.105(0.013)$ & $0.115(0.010)$ & 3.5 \\
\hline Suchá Belá & $79-81$ & 3 & 0 & 0 & 29.6 & $0.139(0.014)$ & $0.160(0.011)$ & 4.2 \\
\hline Trsteník & $82-84$ & 3 & 0 & 0 & 20.6 & $0.113(0.013)$ & $0.135(0.011)$ & 2.4 \\
\hline \multicolumn{5}{|c|}{ total mean (populations separately) } & 27.6 & $0.139(0.014)$ & $0.144(0.009)$ & 3.0 \\
\hline
\end{tabular}


Czech locality at Karlštejn $(\mathrm{I}=0.087)$ and the highest value was computed for the Hungarian population from Regéc $(\mathrm{I}=0.177)$. The total gene diversity (Ht) was 0.157.

\section{POPULATION GENETIC STRUCTURE}

The Neighbor-Joining clustering analysis divided the A. liliifolia samples into seven main clades (Groups A-G; Fig. 4), where clustering of the samples was not strictly associated with their geographical origin and only a weak bootstrap (i.e., values below 15, not shown) support was recorded.

Nevertheless, a certain level of clustering which might be linked with the geographical origin can be observed on the NJ tree. All of the samples from Slovakia appeared in three groups (A-C). Group A represents samples solely from South (Silica) and Central Slovakia. Group B consists of samples from several Slovak localities and one outlying Hungarian sample (Aggtelek). Two samples from Trsteník (SK) together with one sample from Vražba $(\mathrm{CZ})$ are located between Groups A and B. Two samples from Poland, one sample from Regéc (HU), and six samples from Czechia were mixed with samples which originated mainly from Michalovo and Cigánka (SK) and formed Group C. Group D is separated from the previous groups and is represented only by six Czech samples, while the remaining 5 samples from Czechia are located in Group E (4 samples) and F (one sample). All of the samples from South Hungary, together with two Romanian and two Polish samples are present in Group E. Eight out of ten remaining Romanian samples were present in Group F. The samples from North Hungary (Füzér, Regéc) fell into a separate group, Group G (Fig. 4). The Polish samples were spread through the $\mathrm{NJ}$ tree in groups $\mathrm{C}$ (2 samples), E (3 samples), and F (one sample).

Further analysis of the population genetic structure by Bayesian clustering implemented in STRUCTURE suggested a subdivision into two or five clusters (maximum value $\Delta K=57.627$ for $\mathrm{K}=2$ and $\Delta K=16.419$ for $K=5$ ) (Fig. 5). Bayesian clustering for $\mathrm{K}=2$ stressed the genetic differences in the Slovakian populations from Slovenský kras NP (Slovakian karst, Silica) and Pusté pole (W), while all of the remaining samples were highly similar. Subdivision into five groups $(K=5)$ basically reflects the results of the $\mathrm{NJ}$ clustering: i) a unique group of

B

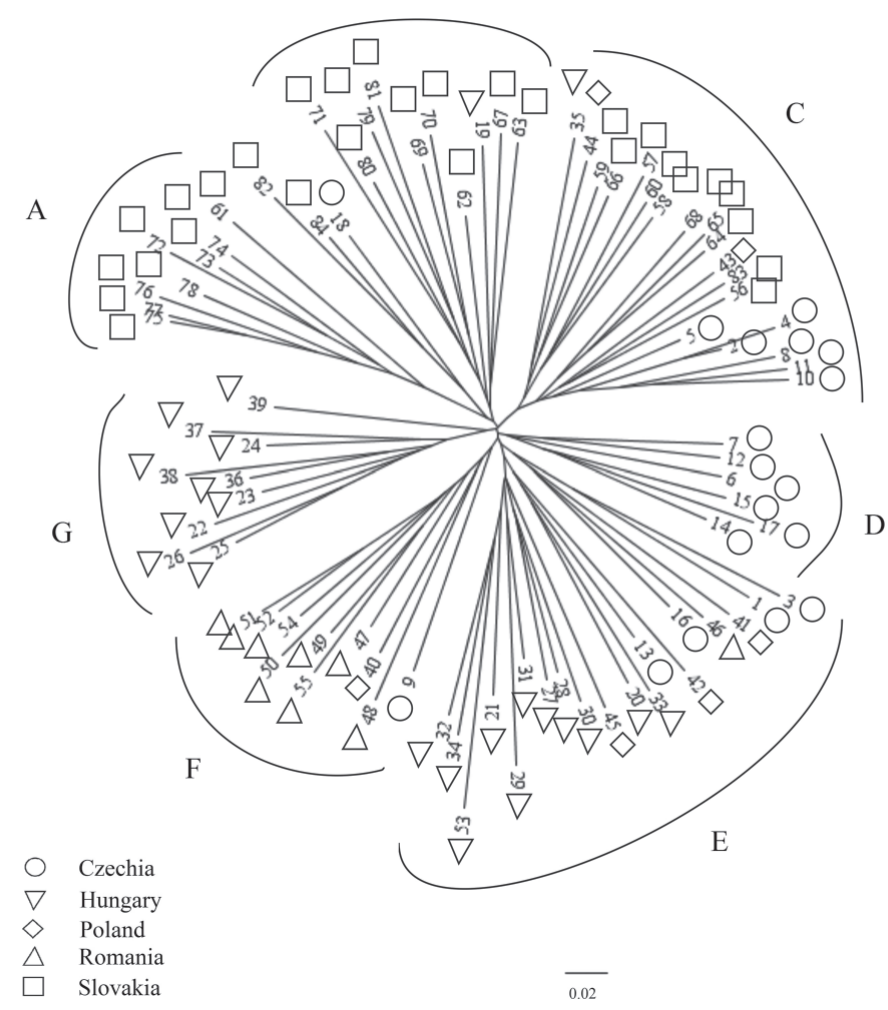

Fig. 4. Unrooted Neighbour-joining dendrogram (based on 291 AFLP markers and Dice similarity matrix) of 84 Adenophora liliifolia samples from five European countries. Putative groups are designed by capital letters A-G. 

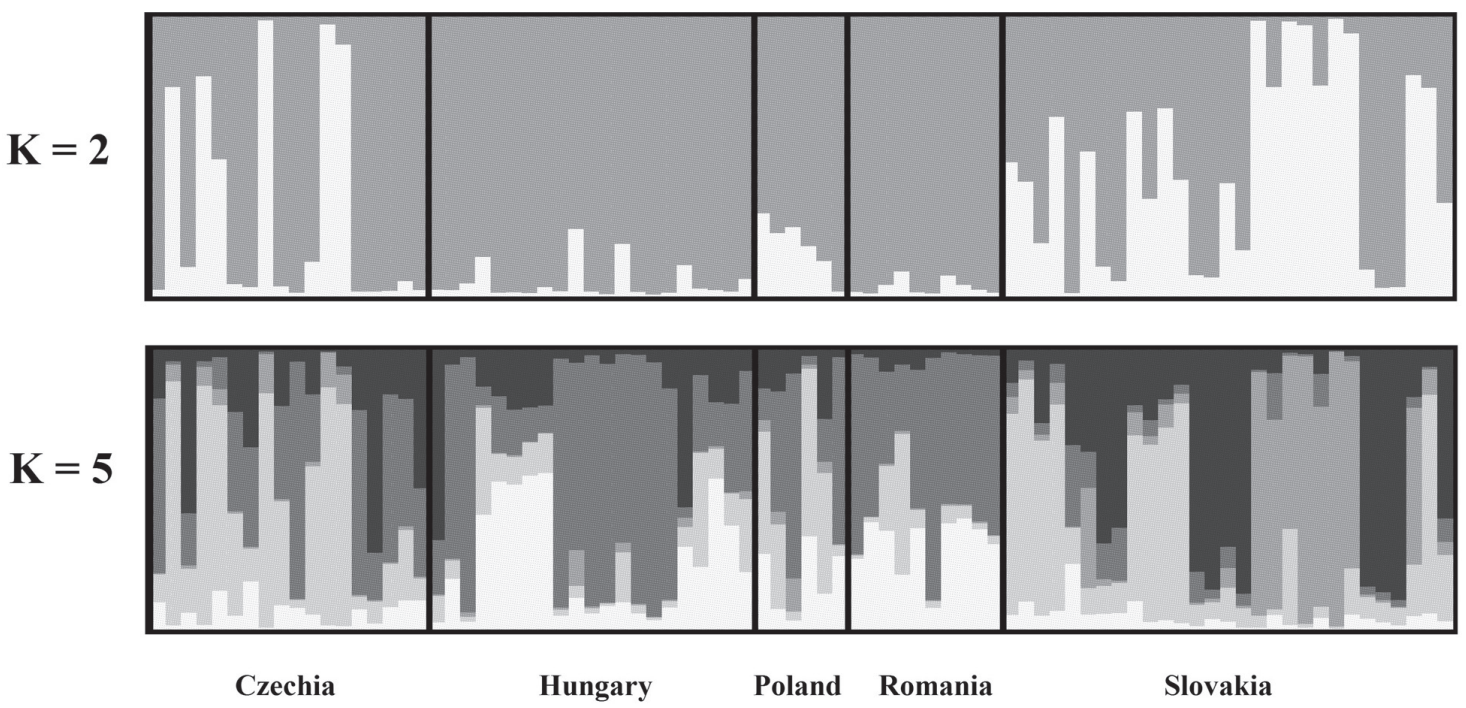

Fig. 5. Results of the STRUCTURE analysis of 84 A. liliifolia samples showing results for $\mathrm{K}=2$ and $\mathrm{K}=5$. Each vertical bar represents one individual with the color representing the probability of assignment to different clusters. The origin of the populations is displayed below the graphics.

Slovakian samples (roughly equal to Group A on the $\mathrm{NJ}$ tree: $\sim \mathrm{NJ}$ Group A); ii) the remaining Slovakian samples sharing a similar genetic background with some of the Czech and Polish samples $(\sim \mathrm{NJ}$ Groups B,C,D $)$; iii) separation of samples from North Hungary $\left(\sim \mathrm{NJ} J^{\text {Group }} \mathrm{G}\right)$; iiii) similarity of the South Hungarian and Romanian samples with some samples from Poland and Czechia ( $\sim$ NJGroups F,E) (Fig. 5).

The AMOVA computations revealed that $22 \%$ of the total genetic variation represents differences among the populations, while $78 \%$ is related to the genetic variation among plants within populations, with $\mathrm{F}_{\mathrm{ST}}=0.125$. The Mantel test revealed no significant correlation between geographical distance and genetic distance or pairwise $\mathrm{F}_{\mathrm{ST}}$ (i.e., lack of genetic isolation by distance; $r=-0.141$, $\mathrm{P}=0.1580$ ), except slightly positive correlations (not significant) of the geographic position of localities (longitude) with polymorphism ( $\mathrm{r}=0.466$, $\mathrm{P}=0.217)$ or genetic diversity $(\mathrm{r}=0.426$, $\mathrm{P}=0.182$ ).

\section{DISCUSSION}

\section{POPULATIONS, SITE CONDITIONS, AND VEGETATION}

Our survey of $A$. liliifolia populations in Central Europe revealed the decline in number of its localities in all of the investigated countries. Comparison of the present survey with historical data from the 19th and early 20th century showed that in the past A. liliifolia had occurred in 20 locali- ties within the phytogeographical district of Czech Thermophyticum, and in 6 localities within the Mesophyticum. At present, the species occurs very rarely in 5 localities of the Czech Thermophyticum (Kovanda, 2000; Prausová and Truhlářová, 2009). In Slovakia, the species is still present in both of the phytogeographical districts of Pannonicum and Carpaticum (Goliášová and Šípošová, 2008). Currently, A. liliifolia grows only in about 10 localities in the Carpathians and their foothills, while historical data describe about 30 former populations in this territory. In Pannonicum A. liliifolia occurs in the Slovenský kras NP (only one verified locality near the Silica village). In Poland, this species was previously found in circa 100 localities within all of the phytogeographical provinces, but nowadays it is only known to occur in approximately $21-22$ of them. Their location in the central and the northeastern part of the country represents the current northern distribution border of A. liliifolia in Europe (Pawłowska, 1972; Ciosek, 2006; Kucharczyk, 2007; Piękoś-Mirkowa, 2008; Rapa, 2012; Kucharczyk et al., 2014; Kapler et al., 2015). Similarly, in Romania, Adenophora is only recorded in 6 out of 34 former localities and in two newly found localities in Transylvania (Indreica, 2011). In Hungary, it is recorded in 7 out of 30 former localities (Farkas and Vojtkó, 2012, 2013). In the Balkan Peninsula, in the former Socialist Federal Republic of Yugoslavia, the species remains common in river valleys, but is supposedly extinct in many localities (Acetto, 2007).

The highest number of A. liliifolia tufts per population were observed in the Slovak localities in 
Muránska planina NP (Cigánka, Trsteník), followed by the Czech locality of Vražba (Tab. 3). This is probably related to the remoteness of these Slovak localities from populated areas and to appropriate management at the locality Vražba (CZ). A. liliifolia shows a high morphological variability related to the site conditions and habitat in which it grows. The tallest individuals were found in oak-hornbeam and beech forests, the smallest individuals were found in meadows (Regéc, Babinské meadows) and also in the Karlické valley which is influenced by inappropriate forest management, where young plants of $A$. liliifolia have been overgrown by juvenile trees and shrubs. The number of stems in a tuft varied from 1 (common at several localities) to 20 (Prejmer, RO). A single stem occurrence was most common in the Karlické valley (CZ), Füzér (HU), and at Suchá Belá (SK), where most of the stems were sterile. The most species rich biotopes were observed at the Czech localities Vražba and Karlštejn, and the Slovak localities at Suchá Belá and Michalovo.

According to the Ellenberg indicators (Ellenberg et al., 1992), A. liliifolia is classified as a heliophilous, thermophilous, and basiphilous species requiring enough moisture and with little to no demand for nitrogen. On the contrary, many current localities (mainly Czech, Polish, and several historical Slovak localities) have a higher content of nutrients that support the development and spread of nitrophilous species including Aegopodium podagraria L., Urtica dioica L., and Stachys sylvatica L. which have become important competitors of A. liliifolia. It is assumed that basiphilous and mesotrophic thermophilous oak forests previously grew in these localities, but that they changed into mesophilous oak-hornbeam forests due to eutrophication (Müllerová et al., 2015) and missing disturbances like pasturage. The soils in the localities of Herculian (RO), Silica (SK), and the Babinské meadows $(\mathrm{CZ})$ were found to have the highest $\mathrm{pH}$ of all of the studied localities because of both calcareous substrate and the greatest nutrient content resulting from a rapid humification process. Our finding of high soil pH in most of the current localities corresponds with other data about the occurence of $A$. liliifolia on calcareous rocks in beech and pine forests, and also in subalpine grasslands in Slovenia (Babij, 2004; Acetto, 2007). In Switzerland (Moser, 1999) and Slovakia (Dražil, 2002), the species grows in calciphilous beech forests (association Cephalanthero damassonii-Fagetum sylvaticae). In Hungary (Siklósi, 1984; Farkas and Vojtkó, 2012, 2013), A. liliifolia was found in riparian forests (association Fraxino pannonicaeUlmetum glabrae Aszód 1935 corr. Soó 1963).

Roleček (2007) states that A. liliifolia belongs to heliophilous species of subcontinental oak for- ests which grow in climatically non-extreme sites. It has a limited ability for long distance dispersal and successional changes from subcontinental oak forests to oak-hornbeam forest or shady mixed oak forests do not facilitate its spreading. It is thought that A. liliifolia could survive in light oak coppices and grazed forests of lower elevations, and also in light forests at higher altitudes, mainly on rocky outcrops, in erosion-prone sites, areas influenced by the grazing of wild animals, and thus generally in various forest ecotones. The distribution of this species followed continually changing light conditions in forests. Válek (Válek in Rohlena and Dostál 1936) provided information about hundreds of $A$. liliifolia individuals that had reappeared in the locality of Vražba (Czechia) at clearings in mixed forests containing spruce after an attack of the moth Lymantria monacha L. The previously shady forest was then replaced temporarily by a non-forest or open forest area. Roleček (2007) states that the best conditions for this species are in the S Ural and in SW Siberia, where the continental climate prevents broadleaf, mesophilous trees and shrubs from extension and where A. liliifolia grows in the hemiboreal forests of Brachypodio pinnati-Betuletea pendulae Ermakov, Korolyuk \& Latchinsky 1991 (Ermakov et al., 1991; Ermakov and Maltseva, 1999; Chytrý et al., 2012). Central European forest habitats have changed a lot since the Preboreal and Boreal period. Once light Preboreal and Boreal forests were later massively replaced by deciduous forests with more closed canopies in Central Europe (Kaplan, 2012). Open forests containing heliophilous trees like Pinus sylvestris L., Betula pendula Roth., and Larix decidua Mill. supposedly occured in Central Europe and SW Siberia about 9,500 years BC; they disappeared from Central Europe due to climate changes and human activities. According to Roleček (2007), there are only fragments of relict hemiboreal forests surviving in Central Europe today. Martynenko (2009) designates the S Ural region as the easternmost part of the distribution range of thermophilous oak forests of class Quercetea pubescentis Doing Kraft ex Scamoni et Passarge 1959, namely Lathyro-Quercion roboris Solomeshch et al. 1989 nom. inval. alliance. According to Roleček et al. (2015), similar vegetation to that present in the $\mathrm{S}$ Ural region appeared in Central Europe after the expansion of oak during the Boreal period, and in suitable places it could resist, although the degree of climate oceanity increased and highly competitive wood species expanded (Fagus sylvatica L., Carpinus betulus L.). This relict vegetation shelters rare species with disjunct distribution, such as A. liliifolia, Veratrum nigrum L., and Dracocephalum ruyschiana L. Patches of light oak or oak-pine forests and forest-meadow eco- 
tones, which are suitable secondary habitats for light-demanding, often basiphilous species, were established by human activities in the Middle Ages. Therefore, A. liliifolia survives in Central Europe mainly in the light edges of forests and in intermittently wet Molinia meadows (Roleček, 2007). The current meadow vegetation of the A. liliifolia locality in the Central Bohemian Uplands PLA is considered as a relict of forest-steppe vegetation which prevailed in this area in the past and was later influenced by prehistoric settlement, agriculture, gradual overgrowing, and eutrophication. Despite these changes, a high level of biodiversity and species of the relict mesic sites vegetation remain here (e.g., A. liliifolia, Potentilla alba L., Serratula tinctoria L.). Adenophora liliifolia was also observed in the shrub association of alliances Berberidion Br.-Bl. 1950 and Prunetalia spinosae R.Tx. 1952, in Peucedano cervariae-Coryletum Kozł. 1925 em. Medw.-Korn. 1952 scrub (Ciosek, 2006; Kovanda, 2000; Kapler et al., 2015), in sunny patches at forest edges of Tilio cordatae-Carpinetum betuli (Kapler et al., 2015), and in mesic meadows (association Anthyllido-Festucetum rubrae Soó, 1971) (Farkas and Vojtkó, 2012, 2013). Hungarian relevés from Regéc and Füzér were identified as the association of Nardo-Molinietum hungaricae (Kovács 1962) Borhidi 2001 (Farkas and Vojtkó, 2013). In Poland, A. liliifolia at its north-easternmost localities (Czarna Białostocka and Dobry Lasek) also grows in a mosaic of ruderal and segetal communities, often with ecotones of thermophilous scrubs and light spruce-pine-oakwoods (Kapler et al., 2015).

\section{GENETIC VARIABILITY \\ AND POPULATION GENETIC STRUCTURE}

To compare the results of our genetic analysis we searched for studies dedicated to plants with an Euro-Sibirian distribution similar to A. liliifolia. Two different species of Stipa L. (Poaceae) were studied by the AFLP method, and populations from their periphery in Central Europe were compared with populations within their main distribution area in Russia (Wagner et al., 2011, 2012). In both cases, the authors did not find any relationship between the size of the population (represented by the number of plants) and the observed genetic diversity, similar to the results of the present study. Nevertheless, this statement has to be proved in the future, due to the low number of analyzed individuals used in our study. In populations of Stipa pennata L., the genetic diversity declined significantly from the distribution's center to its periphery (Wagner et al., 2012). The same trend seems also to be present for A. liliifolia, as we observed only slight correlations between the geographi- cal position of populations (increscent longitude), polymorphism, and heterozygosity (althought not significant). For populations of Stipa capillata L., low values of polymorphism were found both in its distributional center (21.9\%) and on its periphery $(20.0 \%)$, values that are close to the value of polymorphism detected within the present study (average $\mathrm{P}=27.6 \%$ for the analyzed populations, Tab. 5). Similar results (low polymorphism both in the peripheral and the central populations) were observed in the relict steppe species Iris aphylla L. (Wróblewska, 2008). Another example of a species with a similar Euro-Siberian distribution is Ligularia sibirica L., whose populations from the Czechia and Slovakia were analyzed by Šmídová et al. (2011) using allozyme analysis. Similar to our study, the results of the investigated populations of $L$. sibirica showed high genetic diversity within populations $(80.8 \%)$ and a lower level of genetic differentiation between populations $\left(\mathrm{F}_{\mathrm{ST}}=0.179\right)$. Contrary to the results of our study, the genetic distance between populations correlated significantly with the geographic distance, and there was also a significant positive correlation between genetic diversity and population size. However, Šmídová et al. (2011) used codominant allozyme markers (tracing variation in proteins), which generally detect a lower level of genetic variation, contrary to the dominant and highly variable AFLP markers utilized in this study, which allow the direct examination of DNA sequence variation.

There are only a few studies which investigated the genetic diversity of populations of Adenophora spp., including two isozyme based studies by Ge et al. (1999) and Chung and Epperson (1999); and two more recent studies based on ISSR markers by Boronnikova (2009) and Manole et al. (2015). Boronnikova (2009) analyzed four A. liliifolia populations from the Perm region in Russia using ISSR markers, and detected (similarly to our study) a weak population genetic structure and high intrapopulation variation (nearly $84.5 \%$ of the total variation). The expected heterozygosity values ranged from 0.159 to 0.275 , with a mean $\mathrm{H}_{\mathrm{E}}=0.228$. These values are twice as great as the gene diversity values detected in the present study. This can be influence by a) the greater number of sampled plants per population in the study by Boronnikova (2009); and b) the fact that the investigated populations were geographically closer to the species' center of distribution, thus possessing a greater degree of genetic variability. A recent study by Manole et al. (2015) investigated 12 mature specimens of A. liliifolia from one Romanian population using ISSR markers. Also in this study, a relatively high intrapopulation genetic variation was observed as measured by Shannon's index of genotypic diversity (0.812), contrary to our calculations (mean 
value of $\mathrm{I}=0.139$, which may be caused by the different type of molecular markers used and/or the different sample size). Ge et al. (1999) investigated two Adenophora species in China - the endangered A. lobophylla D.Y. Hong and its widespread relative $A$. potaninii Korsh. For these two species, the differentiation among the investigated populations was higher among $A$. potaninii populations $\left(\mathrm{F}_{\mathrm{ST}}=0.155\right)$ than among $A$. lobophylla populations $\left(\mathrm{F}_{\mathrm{ST}}=0.071\right)$. The $\mathrm{F}_{\mathrm{ST}}$ value obtained for A. liliifolia was 0.125 , which is quite close to the results for $A$. potaninii. This result is probably due to the similar geographical distances between the most remote localities of $A$. potaninii and A. liliifolia (ca 850 and $1000 \mathrm{~km}$ respectively), contrary to the weak population genetic structure detected among the A. lobophylla populations, which were located at a maximum distance of $25 \mathrm{~km}$ from each other. In Korea, with respect to the endemic Hanabusaya asiatica Nakai (a genus closely related to Adenophora), there is an apparent pattern of isolation by distance among the assessed populations. Despite the fact that the allozyme differentiation among the populations is low $\left(\mathrm{C}_{\mathrm{ST}}=0.132\right)$, the species maintains a high allozyme diversity $\left(\mathrm{H}_{\mathrm{ES}}=0.217\right)$ (Chung et al., 2001). In A. liliifolia populations, we failed to find a significant correlation between geographical distance and genetic distance or pairwise $\mathrm{F}_{\mathrm{ST}}$.

Adenophora liliifolia is a species with prevailing sexual reproduction and regular generation of viable seeds (personal observation), which has a scattered occurrence in Europe and inhabits different habitats (in terms of abiotic conditions, see text above). The longest distance between the studied localities was more than $1000 \mathrm{~km}$ [between the Babínské meadows (CZ) and Prejmer (RO)] and our field observations showed morphological differences between the localities (e.g., shape of the leaves, presence or absence and different lengths of the leaf petioles, color of the corolla). Based on these observations, we initially expected to observe a clearly resolved inter-population genetic structure; however, this is not what was found.

The relatively high genetic diversity value obtained and the results of the AMOVA analysis showed that the majority of the genetic variation is present within populations. This pattern of genetic variability distribution may be due to vigorous sexual reproduction, which dominates over vegetative spreading within A. liliifolia populations (Manole et al., 2015). Furthermore, the low number of unique markers accompanied by the almost absolute absence of fixed-private markers, low $\mathrm{F}_{\mathrm{ST}}$ and DW values, and weak inter-population genetic structure suggest that the separation of the analyzed populations took place only sub-recently, because of the short time for population differentiation by genetic drift, which would result in the detection of a clear population genetic structure. On the contrary, we detected high overall variation and high similarity of the sampled populations, suggesting frequent gene-flow among populations. This, however, seems unlikely, due to the considerable geographical distance between the sampled localities utilized in this study. Our results rather suggest that there was a large meta-population of A. liliifolia in the Central European area, which has fragmented relatively recently into the isolated populations present today.

Nevertheless, some populations in the Pannonian Biogeographic Region (in Romania, South Hungary, and Slovak populations in Silica and Pusté pole (W) are genetically more different from the other remaining populations, thus these might have been isolated for a longer period of time.

\section{CONSERVATION OF A. LILIIFOLIA}

The conservation of A. liliifolia strongly depends on the specific management supporting its seedlings, which are not vigorous enough to survive without protection (e.g., by removing invasive or nitrophilous species; see e.g., Ciosek, 2006; Manole et al., 2015). Such management may be difficult because of the presence of other protected species, thus it should be planned with respect to the whole locality, not only to a single species.

Recently a conservation program for A. liliifolia was started in Czechia with the aim to find the most successful and efficient way of management for each of the present localities. It aims not only at preserving the natural populations in situ but also at developing appropriate techniques for ex situ preservation (creation of a sterile tissue culture, appropriate storage of seeds in seed banks, experimental germination tests and cultivation in order to identify the critical factors for seedling growth). The other countries of Central Europe suggested a similar approach to protect this species, although without the official funded conservation programs (e.g., Kucharczyk, 2007; Puchalski et al., 2014; Manole et al., 2015).

\section{CONCLUSION}

This study provides overall information about the present condition of Adenophora liliifolia populations in several countries located in Central Europe, combining molecular data with the results of a phytosociological survey. A. liliifolia was found in 6 vegetation units, where it prefers sunny places with moist alkaline soil. The richest populations are in the Polish locality of Kisielany and two Slovak localities - Trsteník and Cigánka (both in Muránska 
planina NP). The greatest numbers of species in the phytosociological relevés were recorded in the Czech localities of Vražba and Karlštejn and in three Slovak localities - Malý Sokol, Suchá Belá, and Michalovo. Light forests and their edges are optimal biotopes for A. liliifolia. Eutrophication, shading, overpopulated wild animals, and expansive broad-leaved herbs are the main factors causing the decline of A. liliifolia populations in Central Europe. Despite the fact that the majority of the investigated populations (except for Slovakia) are rather isolated and geographically distant from each other, our results indicate high interpopulation homogenity, typical for populations with extensive gene flow. The lack of stronger interpopulation differentiation can be explained by the relatively recent fragmentation of a larger population due to shrinking of suitable habitats, their disappearance, or overall changes in landscape management. The findings of the present study show that A. liliifolia populations are not primarily threatened by loss of genetic diversity, but are endangered by loss of suitable habitats. Therefore, a specific management strategy is necessary in most of the localities.

\section{AUTHORS' CONTRIBUTIONS}

Prausová - phytosociological research and analysis in Juice, monitoring of the Czech and Slovak populations; Marečková - monitoring of the Czech and Slovak populations, genetic analysis; Kapler - phytosociological research and monitoring of the Polish populations; Majeský - genetic analysis; Farkas phytosociological research and monitoring of the Hungarian populations; Indreica - phytosociological research and monitoring of the Romanian populations; Šafárová - ecological statistical analysis in Canoco; Kitner - genetic analysis.

\section{ACKNOWLEDGEMENTS}

The study was supported by the funds for Specific research financed by the Ministry of Education of the Czech Republic No. 2121/2011, 2122/2012, $2106 / 2013$ and the Internal Grant Agency of Palacký University (IGA 2015_001 and IGA 2016 001). The Ministries of Environment of the Czech and the Slovak Republics granted us with permission to collect and analyze samples of this species and enter into its localities. We would like to express our thanks to the staff of the investigated protected areas in the Czech Republic and Slovakia, namely to Roman Hamerský, Tomáš Tichý, Josef Mottl, Peter Turis, Drahoš Blanár, Robert Švada, Štefánia Bryndzová, for providing us with information about the localities where A. liliifolia occurs.
We would also like to express our gratitude to Adam Rapa and Marek Ciosek for providing us with samples from the Polish populations. We are grateful to prof. Jerzy Puchalski for support of research on the Polish A. liliifolia localities. We would like to thank František Krahulec for valuable suggestions to the manuscript and Jakub Gamrát for creating of Fig. 1.

\section{REFERENCES}

Aсетто M. 2007. Notulae ad floram Slovieniae, 79. Adenophora liliifolia (L.) DC. Nova nahalisca na Kocevskem in domnevno izginula $\mathrm{v}$ Zasavju. [New localities in the Koćevsko and supposeddly dissappeared ones in Zasavje area.]. Hladnikia 20: 27-40. (in Slovenian)

AdDinsoft. 2015. Xlstat 2015 free trial version. [Software] URL: https://www.xlstat.com/en/download

Anonymous. 2009. Habitats Directive Article 17 Reporting. URL: http://forum.eionet.europa.eu/.../adenophora_lilifoliapdf/ (1.1.2015).

AgentuRA OCHRANY PŘ́́ROdY A KRAJINY ČEsKÉ REPUBLIKY 2005. Půdní mapa ČR. Listy 02-41, 12-12, 12-41, 13-22. [Edice Půdní mapa ČR 1:50 000. 1:50 000]. [Soil map of the Czech Republic]. URL: http://www.nature.cz/publik_syst2/ (1.1.2015) (in Czech)

BABIJ V. 2004. Adenophora liliifolia (L.) Bess. - Navadna obročnica. In: Čušin, B. (ur.) s sod.: Natura $2000 v$ Sloveniji - rastline, 33-35. ZRC SAZU, Ljubljana. (in Slovenian)

Bilz M, Kell SP, MaXted N, and Lansdown RV. 2011. European red list of vascular plants. Publications Office of the European Union, Luxembourg.

BoRonNIKOVA SV. 2009. Genetic variation in Ural populations of the rare plant species Adenophora lilifolia (L.) DC. on the basis of analysis of polymorphism of ISSR markers. Russian Journal of Genetics 45: 571-574. DOI: 10.1134/ S1022795409050081.

Braun-Blanguet J. 1964. Pflanzensoziologie. Wien et New York.

Castroviejo S, Aldasoro JJ, Alarcón M, and Hand R. 2010. Campanulaceae. In: Euro+Med Plantbase - the information resource for Euro - Mediterranean plant diversity. Adenophora liliifolia (L.) A. DC. URL: http://ww2.bgbm. org/euroPlusMed/PTaxonDetail.asp?UUID=07955BD4EE284806-B677-F43413FA8A4E (1.1.2015).

CHÁB J, STRÁNík Z, and EliÁš M. 2007. Geologická mapa České republiky 1 : 500 000. [Map of geology in the CR, 1 : 500 000.] Česká geologická služba. Praha. (in Czech)

Chung MG, and EPperson BK. 1999. Spatial genetic structure of clonal and sexual reproduction in populations of $\mathrm{Ad}$ enophora grandiflora (Campanulaceae). Evolution 53/4: 1068-1078.

Chung MG, Chung MY, and Epperson B. 2001. Conservation genetics of an endangered herb, Hanabusaya asiatica (Campanulaceae). Plant Biology 3: 42-49.

ChytRÝ M. [ed.]. 2007. Vegetace České republiky 1. Travinná a keř́čková vegetace [Vegetation of the Czech Republic 1. Grassland and heathland vegetation.] Academia, Praha, 526 p. (in Czech) 
ChYTRÝ M. [ed.]. 2013. Vegetace České republiky 4. Lesní a křovinná vegetace. [Vegetation of the Czech Republic 4. Forest and Scrub Vegetation.] Academia, Praha, 551 p. (in Czech)

Chytrý M, Ermakov N, Danihelka J, Hájek M, Hájková P, Horsák M, Kočí M, Kubešová S, Lustyk P, OtÝPKová Z, PelánKová B, Valachovič M, and ZelenÝ D. 2012. High species richness in hemiboreal forests of the northern Russian Altai, southern Siberia. Journal of Vegetation Science 23: 605-616.

Cieślak E, and Szelą Z. 2009. Genetic diversity of Galium cracoviense Ehrend.[Rubiaceae]-the Polish endemic plant. Acta Societatis Botanicorum Poloniae 78: 123-129.

Cieślak E, Kaźmierczakowa R, and Ronikier M. 2010. Cochlearia polonica Fröhl. (Brassicaceae), a narrow endemic species of southern Poland: history of conservation efforts, overview of current population resources and genetic structure of populations. Acta Societatis Botanicorum Poloniae 79: 255-261.

Cieślak E, Korbecka G, and Ronikier M. 2007. Genetic structure of the critically endangered Cochlearia polonica (Brassicaceae): efficiency of the last-chance transplantation. Botanical Journal of the Linnean Society 155: 527-532.

Cieślak E, and Szeląg Z. 2010. Genetic diversity of Galium cracoviense, G. oelandicum and G. sudeticum (Rubiaceae). Acta Societatis Botanicorum Poloniae 79: 269-275. DOI: http://dx.doi.org/10.5586/asbp.2010.034

Cieślak E, Cieślak J, Szeląg Z, and Ronikier M. 2015. Genetic structure of Galium cracoviense (Rubiaceae): a naturally rare species with an extremely small distribution range. Conservation Genetics 16: 929-938.

Ciosen MT. 2006. The ladybells Adenophora liliifolia (L.) Besser in forest near Kisielany (Siedlce Upland, E Poland). Biodiversity, Research and Conservation 3-4: 324-328.

Climate Change Knowledge Portal. 2015. The World Bank Group. URL: http://sdwebx.worldbank.org/climateportal/ index.cfm/ (15.10.2015)

Comitetul de Stat al Geologiei - Institutul Geologi CSG-IG. 1968. Harta geologica a RSR. Scara 1:200 000. [Map of geology in Romania, 1 : 200 000]. Foaia 20-Odorhei; Foaia 28-Braşov. Bucuresti. (in Romanian)

Denk T, Frotzler N, and Davitashvili N. 2001. Vegetational patterns and distribution of relict taxa in humid temperate forests and wetlands of Georgia (Transcaucasia). Biological Journal of the Linnean Society 72: 287-332.

Deyuan H, Song G, Lammers T, and Klein L. 2011 . Adenophora Fischer, Mém. Soc. Imp. Nat. Moscou 6: 165. 1823. Flora China 19: 536-551.

Dimitrov D. 2002. Conspectus of the Bulgarian vascular flora. Distribution maps and floristic elements. Ed, 2.

DövÉNYI Z. [ed.]. 2010. Magyarország Kistájainak Katasztere. 2. átdolgozott és bővített kiadás. [Micro regions of Hungary. 2nd revised and extended edition], MTA Földtudományi Kutatóintézet, Budapest, 876 p. (in Hungarian)

DoYle JJ, and DoYLE JL. 1987. A rapid DNA isolation procedure for small quantities of fresh leaf tissue. Phytochemical Bulletin 19: 11-15.

DrAžIL T. 2002. Ls8 Jedlové a jedlovo-smrekové lesy. [Ls8 Fir and fir-spruce forests.] In: Stanová V, Valachovič M [eds.]. Katalóg biotopov Slovenska, 108-109. DAPHNE Inštitút aplikovanej ekológie, Bratislava. (in Slovak)

EARL DA, and VON HOLDT BM. 2012. Structure Harvester: a website and program for visualizing Structure output and implementing the Evanno method. Conservation Genetics Resources 4: 359-361.

EHRICH D. 2006. AFLPdat: a collection of R functions for convenient handling of AFLP data. Molecular Ecology Notes 6: 603-604.

Ellenberg H, Weber He, Düll R, Wirth V, Werner W, and PAulissen D. 1992. Zeigerwerte von Pflanzen in Mitteleuropa. [Indicator values of plants in Central Europe.] Scripta Geobotanica 18: 1-258. (in German)

ERMaKov NB, KorolJov AU, and LASINSKIJ NN. 1991. Floristic classification of mesophilic grassy forests of the South Siberia. Preprint, Novosibirsk, 96 p. (in Russian)

Ermakov NB, and Maltseva T. 1999. Phytosociological peculiarities of South Siberian forest meadows. Annals of Botany 57: 63-72.

European Soil Data Centre Portal. 2008-2015. Soil data and information systems. URL: http://eusoils.jrc.ec.europa. $\mathrm{eu} /$.

EXCOFFIER L, and Lischer HE L. 2010. Arlequin suite ver 3.5: A new series of programs to perform population genetics analyses under Linux and Windows. Molecular Ecology Resources 10: 564-567.

Falush D, Stephens M, and PRitchard JK. 2007. Inference of population structure using multilocus genotype data: dominant markers and null alleles. Molecular Ecology Notes 7: 574-578.

FARJON A, and FILER D. 2013. An atlas of the world's conifers. An analysis of their distribution, biogeography, diversity and conservation status. Brill. 512 p.

FARKas T, and VoJtKó A. 2012. Az Adenophora liliifolia (L.) Besser morfológiai változatosága és cönológiai viszonyai hazánkban. [The Adenophora liliifolia (L.) Besser morphological diversity of plant, cover and conditions in our country.] Kitaibelia 17: 94. (in Hungarian)

FARKAS T, and VOJTKó A. 2013. Az illatos csengettyüvirág (Adenophora liliifolia (L.) Ledeb. ex A. DC.) aktuális helyzete, morfológiai változatossága és élőhelyválasztása Magyarországon. [The current situation of Adenophora liliifolia (L.) Ledeb. ex A. DC., morphological diversity and habitat selection in Hungary.] Botanikai Közlemények 100: 77-103. (in Hungarian)

FEDOROV A. 1978. Flora SSSR. Flora partis Europaeae URSS. Vol. III: Magnoliopsida (Dicotyledones). Izd. "Nauka", Leningrad. (in Russian, Latin summary)

FELSENSTEIN J. 1985. Confidence limits on phylogenies: an approach using the bootstrap. Evolution 39: 783-791.

FIGTREE. 2015. http://tree.bio.ed.ac.uk/software/figtree/ (2015 Oct 15)

Ge S, Wang KQ, Hong DY, Zhang WH, and Zu YG. 1999. Comparisons of genetic diversity in the endangered $A d-$ enophora lobophylla and its widespread congener, A. potaninii. Conservation Biology 13: 509-513.

GoliášovÁ K, and ŠíPošovÁ H [eds.]. 2008. Flóra Slovenska VI/1. [The flora of Slovakia VI/1.] Veda, Bratislava, 419 p. (in Slovak)

GRULICH V. 2012. Red List of vascular plants of the Czech Republic: 3rd edition. Preslia 84: 631-645. 
Hejcman M, Hejcmanová P, Pavlů V, and Beneš J. 2013. Origin and history of grasslands in Central Europe - a review. Grass and Forage Science 68: 345-363.

Hendrych R. and Hendrychová H. 1988. Die Pedicularis Arten der Tschechoslowakei, früher und jetzt. [Species of Pedicularis in the Czechoslovakia, earlier and now.] Acta Universitatis Carolina, series Biologia, 32: 43-465. (in German)

INDREICA A. 2011. Forest habitats with Adenophora liliifola from SE Transylvania. Proceedings of the International Symposium "Forest and sustainable development", Braşov: 283-288.

IUSS WORKING GROUP WRB. 2015. World Reference Base for Soil Resources 2014, update 2015. International soil classification system for naming soils and creating legends for soil maps. World Soil Resources Reports 106. FAO, Rome.

JACOBSSON M, and RosenBerg NA. 2007. CLUMPP: a cluster matching and permutation program for dealing with label switching and multimodality in analysis of population structure. Bioinformatics 23: 1801-1806.

Jones A, Akeroyd J, Beldean M, and Turtureanu D. 2010. Characterization and conservation of xeric grasslands in the Tárnava Mare area of Transylvania (Romania). Tuexenia 30: 445-456, Göttingen. ISSN 0722-494X.

KáČER Š, ANTALíK M, LEXA J, Zvara I, FritzMan R, VlaChoviČ J, Bystrická G, Brodnianska M, Potfaj M, Madarás J, NaGy A, Maglay J, IvaničKa J, Gross P, Rakús M, VozÁrová A, Buček S, Boorová D, Šimon L, Mello J, PoLÁK M, BEZÁK V, Hók J, TETT́́K F, KoneČnÝ V, KuČEra M, ŽEC B, ElečKo M, HRAŠKo L, KováčIK M, and PRISTAŠ J. 2005. Geologická mapa SR M1:50 000. [Map of geology in the SR, $1: 50$ 000]. Štátný geologický ústav Dionýza Štúra. URL: http://mserver.geology.sk:8085/gm50js/ (22. 4. 2013) (in Slovak)

KAPLAN Z. 2012. Flora and phytogeography of the Czech Republic. Preslia 84: 505-573.

KAPLER A, RAPA A, KIEDRZYŃSKI M, BAJDAK T, RADLIŃSKI B, and PuChAlski J. 2015. Current sites of Adenophora liliifolia (L.) Bess.' localities in Poland. Proposed sites for population reinforcement. In: Rybczyński JJ, Puchalski J [eds.]. Monographs of botanic gardens. Vol. 2. Biological Diversity in Poland - the challenges and tasks for botanical gardens and gene banks until 2020, 55-64. PAS BG. - CBDC in Powsin, Warsaw.

KIEDRZYŃSKi M, ZiELIŃSKA K, KIEDRZYŃSKA E, and JAKUBOWSKAGABARA J. 2015. Regional climate and geology affecting habitat availability for a relict plant in a plain landscape: the case of Festuca amethystina L. in Poland. Plant Ecology and Diversity 8: 331-341.

Kitner M, Lebeda A, Doležalová I, Maras M, KŘístková E, Nevo E, Pavlíčer T, Meglic V, and Beharav A. 2008. AFLP analysis of Lactuca saligna germplasm collections from four European and three Middle Eastern countries. Israel Journal of Plant Science 56: 185-193.

KoláR̆ F, LuČAnová M, Vít P, Urfus T, Chrtek J, FÉr T, EHrenDORFER F, and SudA J. 2013. Diversity and endemism in deglaciated areas: Ploidy, relative genome size and niche differentiation in the Galium pusillum complex (Rubiaceae) in Northern and Central Europe. Annals of Botany 111: 1095-1108.
Kolár̆ F, Píšová S, Záveská E, Fér T, Weiser M, Ehrendorfer F, and SUDA J. 2015. The origin of unique diversity in deglaciated areas: traces of Pleistocene processes in northEuropean endemics from the Galium pusillum polyploid complex (Rubiaceae). Molecular Ecology 24: 1311-1334.

KoRzeniak U, and NoBis M. 2004. Adenophora liliifolia (L.) Ledeb. ex A. DC. Dzwonecznik wonny. In: SudnikWójcikowska B, Werblan-Jakubiec H. [red.]. Gatunki roślin. Poradniki ochrony siedlisk i gatunków Natura 2000 - podręcznik metodyczny. [Plant species. Tutorials for Natura 2000' plant species and habitats conservation - a methodical manual.], 69-71. Tom 9. Ministerstwo Środowiska, Warszawa. (in Polish)

Kovanda M. 2000. Adenophora Fisch. - zvonovec. [Adenophora Fisch. - Lilyleaf ladybell.] In: Slavík B.: Květena České republiky 6. Academia, Praha, 748 p. (in Czech)

KozlovsKAJA NW. 1978. Flora Bielorusii, zakonomiernosti jejo formirowanija, naucznyje ispolzovanija i ochrony. [Flora of Belarus, its origin, diversity and protection.] Nauka i Technika, Minsk. (in Russian)

Kucharczyk M. 2007. Dzwonecznik wonny Adenophora liliifolia. Transition Facility 2004. "Opracowanie planów renaturalizacji siedlisk przyrodniczych i siedlisk gatunków na obszarach Natura 2000 oraz planów zarzadzania dla wybranych gatunków objętych Dyrektywa Ptasia i Dyrektywa Siedliskową.” [,Development of the renaturalization (restoration) plans for the Natura 2000 habitats and other habitats associated with community Iimportant species, listed in EU Habitat Directive and Bird Directive appendices.“] Lublin. [http://natura2000. mos.gov.pl/natura2000/pl/dokumenty/n4/4068.pdf ] (in Polish)

KucharczyK M, RaPA A, and ZagorzaleK S. 2014. Dzwonecznik wonny Adenophora liliifolia (L.) Besser. - CR. In: Kaźmierczakowa R, Zarzycki K, Mirek Z (eds.), Polska Czerwona Ksiega Roślin. Paprotniki i rośliny kwiatowe. [Polish Red Data Book of Plants. Pteridophytes and flowering plants. Third edition revised and expanded.], 504-506. Wyd. Instytut Ochrony Przyrody PAN, Kraków, p. 896. (in Polish, English summary).

Manole A, Banciu C, and Indreica A. 2015. Genetic diversity within a newly identified population of Adenophora liliifolia (L.) A. DC. in Romania: implications for conservation. Annals of Forest Research 58(2). URL: http://www. afrjournal.org/index.php/afr/article/viewFile/389/432 (19.8.2015).

MARHOUL P. and TuROÑová D. [eds.]. 2008. Zásady managementu stanovišt' druhů $v$ evropsky významných lokalitách soustavy Natura 2000. Metodika AOPK ČR. [Principles of management in habitats of species at sites of European importance Natura 2000. Methodology of Agency for nature protection and landscape conservation in the Czech Republic.] Praha, 163 p. (in Czech)

MARTiNovskÝ JO. 1967. Srovnávací fytogeografická studie tzv. Babinských orchideových luk a travinných společenstev jim podobných. [Phytogeographical comparative study of Babinské orchid meadows and similar grassland plant communities.] Mostecko a Litvínovsko. Regionalni Studia, series Naturae, Most, 4: 45-93. (in Czech)

MARTyNEnKo VB. 2009. Syntaxonomy of forests of South Ural as a theoretical outline of their systematic protection. 
PhD. dissertation. Laboratory of geobotany a vegetation protection in Ufim. (in Russian)

Meusel H, and JÄGER EJ. 1992. Vergleichende Chorologie der zentraleuropäischen Flora. (3). [Comparative chorology of the Central European Flora. (3).], Jena, 491 p. (in German)

Minai E. 1975. Depresiunea Braşovului. Studiu climatic. [Brasov Depression. Climatic study]. Ed. Academiei Române, Bucureşti. (in Romanian)

MikLós L. [ed.]. 2002. Atlas krajiny Slovenskej republiky. [Landscape Atlas of the Slovak Republic.] Ministertvo životného prostredia SR, Bratislava, Agentúra životného prostredia. Banská Bytrica, 342 p. ISBN 80-88833-27-2. (in Slovak)

Moser D. 1999. Merkblätter Artenschutz, Blütenpflanzen und Farne. [Leaflets about species conservation, flowering plants and ferns.] Adenophora liliifolia, 36-37. Buwal/Skew/ ZDSF /Pronatura, Schweiz. (in German)

Müllerová J, Hédl R, and SzaBó P. 2015. Coppice abandonment and its implications for species diversity in forest vegetation. Forest Ecology and Management 343: 88100.

One Geology - Europe Portal. 2015. URL: http://onegeologyeurope.org/. (15.10. 2015)

PAVlíčEK BA, HRdA S, and Flegr J. 1999. FreeTree - freeware program for construction of phylogenetic trees on the basis of distance data and bootstrap/jackknife analysis of the tree robustness, Application in the RAPD analysis of the genus Frenkelia. Folia Biologica 45: 97-99.

PAWŁOWSKA S. 1972. Charakterystyka statystyczna i elementy flory polskiej. [Floristic statistics and elements of the Polish flora.] In: Szafer W, Zarzycki K [eds.]. Szata roślinna Polski. [The vegetation of Poland.], Tom I, 129-206. PWN, Warszawa. (in Polish)

Peakall R, and Smouse PE. 2006. GENALEX 6: genetic analysis in Excel. Population genetic software for teaching and research. Molecular Ecology Notes 6: 288-295.

PiEkoś-Mirkowa H. 2008. EX - Dzwonecznik wonny Adenophora liliifolia (L.) Besser. In: Mirek Z, Piękoś-Mirkowa $\mathrm{H}$ [eds.]. Czerwona ksiega Karpat polskich. Rośliny naczyniowe. [Red data book of the Polish Carpathians. Vascular plants. ], 336-337. Instytut Botaniki im. W. Szafera, Instytut Ochrony Przyrody PAN, Kraków. (in Polish)

Plieninger T, Hartel T, Martín-López B, Beaufoy G, Bergmeier E, Kirby K, Montero MJ, Moreno G, Oteros-Rozas E, and VAN UYTVANCK J. 2015. Wood-pastures of Europe: geographic coverage, social-ecological values, conservation management, and policy implications. Biological Conservation, 190: 70-79.

Prausová R, and TruHLÁŔovÁ K. 2009. Zvonovec liliolistý (Adenophora liliifolia) v evropsky významné lokalitě Vražba v lesním komplexu u obce Habřina na Královéhradecku. [Adenophora liliifolia in the European important locality Vražba in the forest complex near the village Habřina, at the outskirt of Hradec Králové.] Východočeský sborník prírodovědný. Práce a studie 16: 83-110. (in Czech)

Puchalski J, NiemczyK M, Walerowski P, Podyma W, and Kapler A. 2014. Seed banking of Polish endangered plants - the FlorNatur Project. Biodiversity Research and Conservation 34: 65-72. DOI: 10.2478/biorc-2014-0005)

RAPA A. 2012. Nowe stanowisko dzwonecznika wonnego Adenophora liliifolia w Dąbrowie koło Zaklikowa (Wyżyna
Lubelska). [New locality of Adenophora liliifolia in Dąbrowa near Zaklików (Lublin Upland).] Chrońmy Przyrodę Ojczysta 68 (1): 70-74. (in Polish)

Ravazzi C. 2002. Review of Palaeobotany and Polynology 120:131.

Rohlena J, and Dostál J. 1936. Příspěvky k floristickému výzkumu Čech XII. [Contributions to floristic research of Bohemia XII.] Časopis Národniho Musea, sectio Naturae, Praha, 110: 1-24. (in Czech)

ROLEČEK J. 2007. Vegetace subkontinentálních doubrav ve střední a východní Evropě. [Vegetation of subcontinental oak forests in Central and Eastern Europe.]. Ph.D dissertation, University of Masaryk, Brno, 203 p. URL: http:// www.sci.muni.cz/botany/rolecek/dizertacka_rolda.pdf. (15.10.2015) (in Czech)

ROLEČEK J, ČORNEJ II, and TOKARJUK AI. 2014. Understanding the extreme species richness of semi-dry grasslands in east-central Europe: a comparative approach. Preslia 86: $13-34$.

RolečEK J, HÁJEK M, KARLíK P, and NovÁK J. 2015. Reliktní vegetace na mezických stanovištích. [Relict vegetation on mesic sites.] Zprávy České botanické společnosti, Praha 50: 201-245.

RosenBERG NA. 2004. Distruct: a program for the graphical display of population structure. Molecular Ecology Notes 4: 137-138.

SCHLÜTER PM, and HARRIS SA. 2006. Analysis of multilocus fingerprinting data sets containing missing data. Molecular Ecology Notes 6: 569-572.

SCHNitTler M, and Günther K. 1999. Central European vascular plants requiring priority conservation measures - an analysis from national Red Lists and distribution maps. Biodiversity and Conservation 8: 891-925.

SiKLósi E. 1984. The flora of the pits in the Nature Preservation Area of Ócsa. Studia Botanica Hungarica 17: 41-54.

SMELANSKY I, KoROLUYK A, and ARTEMOV I. 2004. Protection of steppe communities and plant conservation: a case of one Russian territory. URL: http://savesteppe.org/docs/2004 Smelansky_et_al-Protection-of-steppe-communities.pdf (5.1.2016)

Šmídová A, Münzbergová Z. and PlačKová I. 2011. Genetic diversity of a relict plant species, Ligularia sibirica (L.) Cass. (Asteraceae). Flora 206: 151-157.

StatSoft. 2015. Statistica 12. URL: http://www.statsoft.cz (28.11.2015)

SZAFER W. 1946-1947. Flora plioceńska z Krościenka nad Dunajcem. [The Pliocene flora of Krościenko in Poland.] I. General Part. II. Descriptive Part. Rozprawy Wydziału Matematyczno-Przyrodniczego PAU 72, dz. B. 1 \& 2 Kraków. (in Polish, English summary).

SzAFer W. 1954. Plioceńska flora okolic Czorsztyna i jej stosunek do plejstocenu. [The Pliocene flora of the environs of Czorsztyn and its relation to Pleistocene flora.] Prace Instytutu Geologii, Warszawa. (in Polish with English summary).

SZYMURA T. 2012. How does recent vegetation reflect previous systems of forest management? Polish Journal of Ecology 60: 859-862.

TACIK T. 1971. Rodzina: Campanulaceae, Dzwonkowate. In: Pawłowski B, Jasiewicz A. [eds.]. Flora polska. Rośliny naczyniowe Polski i ziem ościennych. [Flora of Poland. 
Vascular plant species of Poland and adjacent countries.]. Vol. 12, 50-99. PWN, Warszawa - Kraków. (in Polish).

TER BRAAK CJF, and ŠMILAUER P. 2002. CANOCO reference manual and CanoDraw for Windows User's guide: software for canonical community ordination (version 4.5). Ithaca, NY: Microcomputer Power.

TICHÝ L. 2011 . Juice. URL: http://juice.trenck.cz (15.4.2015).

Tolasz R. 2007. Atlas podnebí Česka. [Climate Atlas of the Czech Republic.] Český hydrometeorologický ústav, Praha. ISBN 978-80-244-1626-7 (in Czech)

Urgamal M. 2014. Additions to vascular flora of Mongolia - II. URL: https://www.researchgate.net/publication/271328603_ADDITIONS_TO_THE_VASCULAR_ FLORA_OF_MONGGOLIA_-II.(5.1.2016)

VEKEMANS X. 2002 . AFLP-SURV version 1.0. Distributed by the author. Laboratoire de Génétique et Ecologie Végétale, Université Libre de Bruxelles, Belgium

Vladimirov V, Dane F, Stafnović V, and Tan K. 2009. New floristic records in the Balkans: 11. Phytologia Balcanica 15: 431-452.

Vолтко́ A. 2013. Az Adenophora liliifolia új előfordulása a Tornai-karszton. [The new occurence of Adenophora liliifolia in Torna karst.] Kitaibelia 18: 181-182. (in Hungarian)

Vos P, Hogers R, Bleeker M, Reijans M, Vandelee T, Hornes M, Frijters A, Pot J, Peleman J, Kuiper M, and Zabeau M. 1995. AFLP - a new technique for DNA-fingerprinting. Nucleic Acids Research 23: 4407-4414.

VuKoJičić S, LaKuŠić D, Jovanović S, MaRin PD, Tomović G, SabovlJević M, Sinżar-Sekulić J, CviJan M, Blazencić J, and Stevanović V. 2011. University of Belgrade Herbari$\mathrm{um}$ - treasury of data and challenges for future research on the occasion of the 150th anniversary of University of Belgrade Herbarium. Botanica Serbica 35: 163-178.

WAGNer V, DuRKa W, and HENSEn I. 2011. Increased genetic differentiation but no reduced genetic diversity in peripheral vs. central populations of a steppe grass. American Journal of Botany 98: 1173-1179.

Wagner V, Treiber J, DANihelka J, Ruprecht E, Wesche K, and HENSEN I. 2012. Declining genetic diversity and increasing genetic isolation towards the range periphery of Stipa pennata, a Eurasian feather grass. International Journal of Plant Science 173: 802-811.
WiLiams S, and Gotin S. 2012. Catalyzing sustainability of the wetland protected area system in Belarusian Polesie through increased management efficiency and realigned land use practices. Evaluation Report. Government of the Republic of Belarus, Ministry of Natural Resources and Environmental Protection, United National Development Program (UNDP), Minsk, p. 89. [mscr].[http://www.thegef.org/gef/sites/thegef.org/files/ gef_prj_docs/GEFProjectDocuments/M\&E/TE/FY2012/ UNDP/Biodiversity/TEs/2894_GEFID\%202104_TE_Belarus_Polesie_TE_Combined.pdf, 18.4.2016]

Witkowski ZJ, Król W, and Solarz W. [eds.]. 2003. Carpathian List of Endangered Species. WWF and Institute of Nature Conservation, Polish Academy of Sciences, ViennaKrakow, 64 p. ISBN 83-918914-0-2

Working Group for Vegetation Science. 2011. Expertní systém Vegetace České republiky. URL: http: /www.sci.muni.cz/ botany/vegsci/expertni_system.php?lang $=\mathrm{cz} /(1.1 .2015)$.

Working Group on Vegetation Research. 2012. Centrálna databáza fytocenologických zápisov (CDF) na Slovensku. URL: http://ibot.sav.sk/cdf/twins 1.htm (1.10.2015).

WRÓBlewSKA A. 2008. From the center to the margins of geographical range: molecular history of steppe plant Iris aphylla L. in Europe. Plant Systematics and Evolution 272: 49-65.

WRÓBLEWSKA A. 2013a. High genetic diversity within island-like peripheral populations of Pedicularis sceptrum-carolinum, a species with a northern geographic distribution. Annales Botanici Fennici 50: 289-299.

WRÓBLEWSKA A. 2013b. The phylogeographical and population genetic approach to the investigation of the genetic diversity patterns in self-incompatible clonal and polyploid Linnaea borealis subsp. borealis. Botanical Journal of the Linnean Society 173: 64-76.

WRÓBlEWSKA A. 2014. Genetic diversity and spatial genetic structure of Chamaedaphne calyculata (Ericaceae) at the western periphery in relation to its main continuous range in Eurasia. Folia Geobotanica 49: 193-208. 